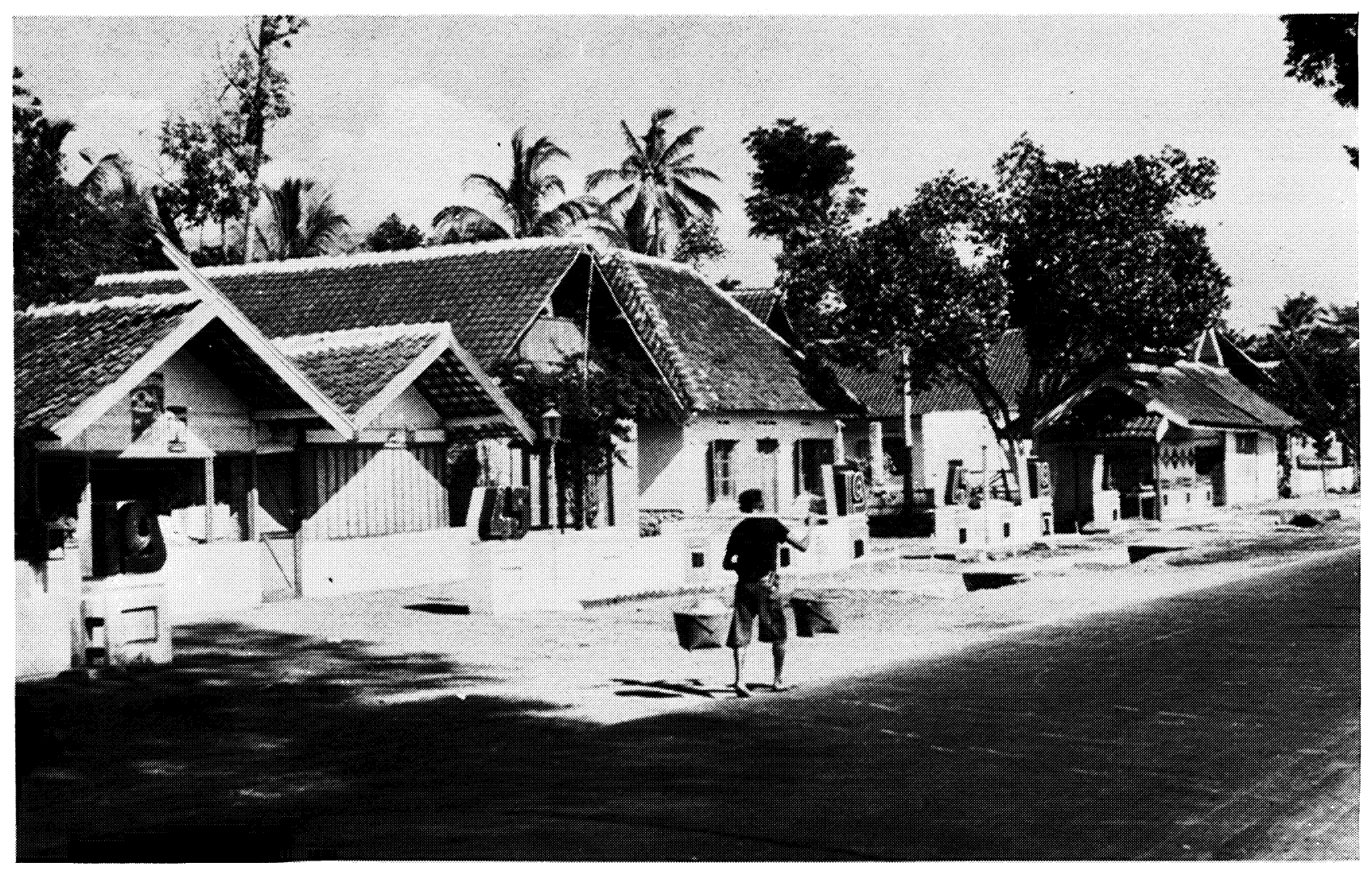

Roadside village between Malang and Selecta 


\title{
NOTES ON CONTEMPORARY INDONESIAN POLITICAL COMMUNICATION
}

\author{
Benedict R. O'G. Anderson
}

With the appearance in 1970 of Indonesian Political Thinking, students of Indonesian society and politics were for the first time presented with a wide-ranging collection of writings and speeches by important Indonesian politicians and intellectuals in the post-1945 period. ${ }^{1}$ The timing of its publication was not fortuitous: it clearly reflected a steadily growing scholarly interest in Indonesian ideology and political discourse. ${ }^{2}$ Recent work by Dahm, Weatherbee, Legge and Mortimer has been devoted to pioneering analysis of important segments of Indonesian political thought. ${ }^{3}$ Their writings show not only how rich this field of enquiry is, but also how much research still needs to be done.

At the same time it is useful to recognize that the materials used in this genre of research ba specialized represent a peter particular type of political communication. In general, they take the form of more or less studied, quasi-literary and printed

1. Herbert Feith and Lance Castles, eds., Indonesian Political Thinking, 1945-1965 (Ithaca, N.Y.: Cornell University Press, 1970). For a useful critique, see Alfian, "Indonesian Political Thinking': A Review," Indonesia, 11 (April 1971), pp. $193-200$.

2. In addition, a number of translations of important individual texts by Indonesian political leaders have been published. These include: Sutan Sjahrir, Out of Exile, trans. Charles Wolf, Jr. (New York: John Day, 1949); Mohammad Hatta, Past and Future (Ithaca, N.Y.: Cornel1 Modern Indonesia Project, 1960); Sukarno, $\overline{\text { Mar- }}$ haen and Proletarian, trans. Claire Holt (Ithaca, N.Y.: Cornell Modern Indonesia Project, 1960); D. N. Aidit, The Selected Works of D. N. Aidit, 2 vols. (Washington, D.C.: U.S. Joint Publications Research Service, 1961); A. H. Nasution, Toward a People's Army (Djakarta: Delegasi, 1964); A. H. Nasution, Fundamentals of Guerrilla Warfare (New York: Praeger, 1965); Sutan Sjahrir, Our Struggle, trans. Benedict Anderson (Ithaca, N.Y.: Cornell Modern Indonesia Project, 1968); Sukarno, Nationalism, Islam and Marxism, trans. Karel Warouw and Peter Weldon (Ithaca, N.Y.: Cornell Modern Indonesia Project, 1970); and T. B. Simatupang, Report from Banaran, trans. Benedict Anderson and Elizabeth Graves (Ithaca, N.Y.: Cornell Modern Indonesia Project, 1972); Mohammad Hatta, Portrait of a Patriot (The Hague: Mouton, 1972).

3. Bernhard Dahm, Sukarno and the Struggle for Indonesian Indepence (Ithaca, N.Y.: Cornell University Press, 1969); Donald Weatherbee, Ideology in Indonesia: Sukarno's Indonesian Revolution (New Haven: Yale University, Southeast Asia Studies Monograph Series No. 8, 1966); John Legge, Sukarno (New York: Praeger, 1972); Rex Alfred Mortimer, "The Ideology of the Communist Party of Indonesia under Guided Democracy, 1959-1965" (Ph.D. thesis, Monash University, 1970). See also Rudolf Mrázek, "Tan Malaka: A Political Personality's Structure of Experience," Indonesia, 14 (October 1972), pp. 1-48. 
statements of positions--whether they reach the scholar as printed speeches, printed articles or printed books. Almost invariably, they are exegetic in character, addressed to particular audiences to combat alternative exegeses, arguments and appeals - in fas are sel-jem. In such circumstances, it is understandable that in his introduction to Indonesian Political Thinking, Herbert Feith tentatively characterized the overall body of Indonesian political thought as "diffusely moral," "optimistic," and marked by "a tendency to see society as undifferentiated." 4 Yet while these traits may well be characteristic of the political communication with which he was concerned, it could be argued that they are less "typically Indonesian" (or typically "Asian" or "Third World," as Feith proposes), than typical of a certain genre of utterance. In such a perspective, these traits may seem no more surprising than moralism in sermons, or sarcasm in satire. One could also suggest that scholars have focused their attention so exclusively on one par type of political communication that by unconscious synecdoche the part has literally been taken for the whole. In the process, other important modes of political communication and expression have been neglected, which, if analyzed, would throw a rather different light on Indonesians' conceptions of their politics. Two such modes, which for convenience I shall call "direct speech" and "symbolic speech," will be discussed below, though, owing to the nature of the material to hand and the substantive purpose of this essay, sonly the second will be utilized at any length.

\section{Direct Speech}

"Direct speech" of overwhelming bulk of political communication in any society: gossip, rumors, discussions, arguments, interrogations and intrigues. Yet despite the vast quantity of such communication, almost all of it escapes the academic eye. What is observed is seldom reported directly, but rather is congealed into indirect speech: typically in the form "rumors circulated that . . .", "the interviewee told the author that at the party conference. . ." and so forth. In the process, the communication is transformed, taken out of its live context, and turned into an illustration or a symbolic representation. The message has become abstract, general and printed. At the same time, such communication is rarely accorded the status of speech qua speech, capable in itself of speaking directly to Indonesian political concerns. Yet even the most marginal observation or participation in Indonesian political life shows that such utterance is simply another mode of political communication--as it were playing ngoko to the krama of Indonesian Political Thinking. ${ }^{5}$ As might be expected from a ngoko mode, this type of speech is rarely "moralistic" or "optimistic"; nor does it present Indonesian society as an "undifferentiated whole."

In part, neglect of this type of communication has its roots in scholarly convention. Krama communication, organized and printed,

4. Feith and Castles, Indonesian Political Thinking, p. 18.

5. Krama and ngoko are respectively the main "high" (polite, formal) and "low" (intimate, informal) levels of Javanese speech. For a discussion of krama and ngoko forms in Indonesian political discourse, see my "The Languages of Indonesian Politics," Indonesia, I (April 1966), pp. 89-116. 
appears more geredible, more permanent, and more replicable, in the sense that different scholars can at least read the same texts if they can rarely hear the same argument or witness the same conference or intrigue. Analysis based on unreplicable interviews, overheard chat, or whatever, seems tenuous, arbitrary and problematic. Unless "checked" by krama sources, therefore, ngoko messages are of dubious value. Most often, they are either aggregated and used to describe a political force or reality ("stories circulated that...") or introduced raw into the analysis as "quotations from field notes"--colorful illustrations of themes derived from the study of krama documents.

The problem is, of course, more than one of etiquette. Academics, particularly if they are foreigners, are disadvantaged in gaining effective access to many types of ngoko communication. The spoken word is ephemeral, and by this very fact in itself imposes high linguistic and mnemonic demands on the observer-analyst. Beyond that, much ngoko speech cannot take place if the foreigner is looking on--he tends to kramanize things with his alien presence. Even in the intimacy of the private interview, the "subject" (object?) usually suspects that what he says will end up as printed exegesis, and under the guise of spontaneity confides in krama to his recording angel.

Yet some ngoko discourse clearly is available in more or less untransmuted forms. In them, aliens can observe, at any time, Indonesians talking, not to the world or to the faithful, but to and against each other, sometimes even to themselves. Rare as they may be, these utterances, by taking printed form, have lost their ephemerality, and come to assume real documentary status. Some notable examples are the stenographic records of the discussians of the Sanyo Kaigi (Council of Advisers), the Badan Penjelidik (Investigating Committee) and the Panitia Persiapan Kemerdekaan Indonesia (Committee for the Preparation of Indonesian Independence) in the late Japanese period; ${ }^{6}$ and the records of the DPR (Parliament) and Konstituante (Constituent Assembly) in the period after independence. ${ }^{7}$ In all these texts ngoko and krama speech are mixed--the talk varying widely in spontaneity and informality--but the ngoko element is important and sometimes even preponderant. (In most of these cases, Indonesians are in real dialogue with one another and foreigners are not present as sympathetic censors.) Most voluminous of al1 are the stenographic proceedings of the Extraordinary Military Tribunals which, since 1966 , have judged and condemned some dozens of left-wing military officers and civilian politicians. 8 Although these documents have long been available, the tendency has been to try to mine them for content (historical fact) rather than for form and meaning (political thought).

6. A partial translation of one extended Sanyō Kaigi discussion is contained in my "The Problem of Rice," Indonesia, 2 (October 1966), pp. 77-123. A somewhat tampered-with version of the debates of the other two bodies is contained in Muhammad Yamin, ed., Naskah persiapan Undang-Undang Dasar 1945 (Djakarta: Jajasan Prapantja, 1959-60), Vol. I.

7. See Ichtisar Parlemen; Risalah Pexundingan Dewan Perwakilan Rakjat; Tentang Dasar Negara Republik Indonesia dalam Konstituante (Djakarta?: n.p., n.d. [1958?]).

8. It is rather sad that it should be such records of judicial interrogation, where the battle of wits must be at its sharpest, where the stakes, at least for the accused, are so high, and where all parties, for their own reasons, are deeply concerned to question, justify and accuse, that give the alien his keenest sense of ngoko exchange. 
Symbolic Speech

If direct speech often eludes the academic eye because of its fluid and ephemeral nature, symbolic speech escapes attention for rather different reasons. One understands that public monuments and rituals, cartoons, films and advertisements are modes of political communication. But their grammar may be perplexing, the relation of form and content at once more salient and more ambiguous. More than printed speech, these visual condensations of significance find their meanings shift, deepen, invert or drain away with time. Since their audiences are necessarily fleeting and anonymous, context is allimportant, yet singularly problematic to the would-be interpreter. For example, on August 17, 1945, a new-made Red-White national flag was flown at Sukarno's side as he read the historic Proclamation of Indonesian Independence. Twenty-three years later, on August 17, 1968, the same flag was flown again for the last time. In the meantime, it had become a pusaka (heirloom). The red had faded to the color of dried blood, the white to ashen gray. On all sides there fluttered hundreds of new-made flags, brilliant in the morning sun. In 1945 , can one doubt it, the flag had expressed an extraordinary hope and exaltation. In 1968, who could be sure what its final flying meant, amidst the hundred replicas, either to those who flew it or those who watched it fly?

In what follows below, I will try to show some of the meanings of the symbolic speech of the New Order era, both to illustrate, however tentatively, a method of interpretation, and to suggest how such interpretation throws light on the "political thinking" of the period. I will attempt to show common elements in a variety of symbolic speech-cartoon, monument, doctrine and film--though admittedly in a loose and rather fragmented way. In a number of instances, meanings may best be brought out by contrast with the symbolic utterance of an earlier time; where this seems the case, the contrast is explicitly drawn.

\section{Cartoons}

of all the forms of visual political communication, cartoons are perhaps the most readily decipherable. Particularly since they frequently make use of written words, they seem closest to conventional printed documents. Since they are usually responses to particular historical events, they can, on one level at least, be mined for their "factual" content. 9 A book of Herblock cartoons, for example, tells the reader a great deal that is concrete and specific about American politics in various phases of the postwar era. But one would miss a good deal, I think, if one studied the cartoons from this perspective alone. Form may tell as much as content. It may be useful, to demonstrate this point, to look at the work of two very successful Indonesian cartoonists, and observe not only the targets of their attacks, but also the way in which the form of their cartoons communicates another type of meaning altogether.

9. A good example of this approach is Ernest F. Henderson, Symbol and Satire in the French Revolution (London: Putnam's Sons, 1912). 
The elder of the two cartoonists is Sibarani, who made his reputation as editorial cartoonist for the sensationalist left-wing daily Bintang Timur in the late 1950's and early 1960's. The younger is Johnny Hidajat, perhaps the most popular of New Order cartoonists, working for Pos Kota, a sensationalist right-wing paper sponsored by the Djakarta municipal authorities, and for a variety of weeklies, particularly the very successful Stop (partly modeled on Mad magazine). Unsurprisingly, given his political affiliations, Sibarani's targets were the right-wing political groups of the day, particularly the civilian and military politicians associated with the PRRI rebelion of 1958-59, as well as their American, British and Kuomintang supporters. Hidajat's targets are much less well-defined, but as we shall see, they appear to be corruption, greed, 1 awlessness and cynicism. But let us first look at the cartoons before attempting any further analysis. Though jokes should really never be explained, it may be necessary to commit the gaffe in the present context.

Cartoon I-A. John Foster Dulles flies a political kite--the PRRI Prime Minister, Sjafrudin Prawiranegara. But the kite is immobile, hopelessly entangled in the Rakjat (People) Tree.

Cartoon I-B. As the dollar sun shines, Foreign Capital greedily swallows up the produce of Indonesia's soil, digests it and excretes. Indonesian capitalists feed on the excrement, digest it and excrete in turn. An unnamed figure, presumably representing the common people, feeds on what is left.

Cartoon I-C. The caption tells us that the sinister sneezing face labeled Anti-Communist is that of former Vice-President Hatta. In the brain bubble the following ideas: Defend Dutch Capital! Smash the PKI! Overthrow the Sukarno regime! Join SEATO! Bring down the government! Irian niet nodig! (Dutch for "isn't necessary!"). Hatta's teeth are caricatures of leading PRRI figures. One can identify (top row): Major Somba, Des Alwi, Lt. Co1. Saleh Lahade, Col. Zulkifli Lubis, Col. Dahlan Djambek and Runturambi; (bottom row): Lt. Col. Achmad Husein (as a pig), Col. Simbolon, Lt. Co1. Ventje Sumual, Sjafrudin Prawiranegara, Sumitro Djojohadikusumo (?), and Burhanuddin Harahap.

Cartoon I-D. Outside the concentration camp at Ladang Lawas (in West Sumatra, where the PRRI forces held many left-wing militants prisoner in 1958), Masjumi leader Mohammad Natsir (identified as Himmler/Natzir), goose-steps. His body has been turned into a swastika, as has the Masjumi emblem (crescent moon and star) on his shoulder. His sword is labeled Holy War.

Cartoon I-E. The Statue of Liberty, in the guise of President Eisenhower, brandishes the severed head of Jimmy Wilson, a young black executed for stealing $\$ 1.95$ in the late 1950's. The torch of freedom has become a bleeding head, the aura glitters with dollars, and the book has been replaced by a blood-stained sword.

Cartoon I-F. The PRRI cart is drawn by a donkey named $S j a f r u d i n$ Prawiranegara. On it ride Allan Pope (the ClA operative and pilot shot down by central government forces near Ambon in May 1958), Tasrif (alleged mastermind of the attempted assassination of President Sukarno in November 1957) and the executioners of Situdjuh and Ladang Lawas (two prison camps in West Sumatra).

Cartoon I-G. A memorial to the militants who died at the hands of the PRRI. The caption reads: Arise! 

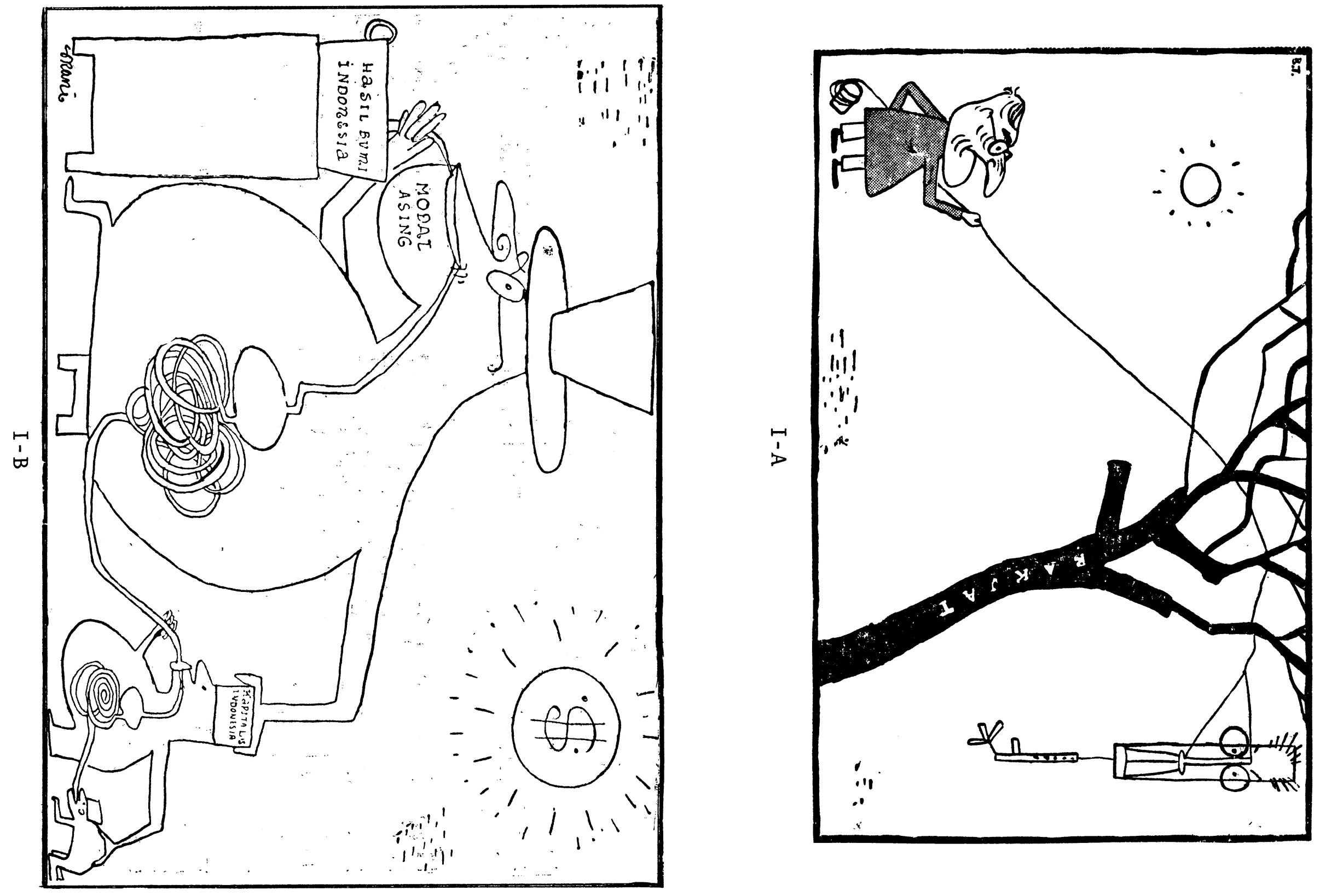


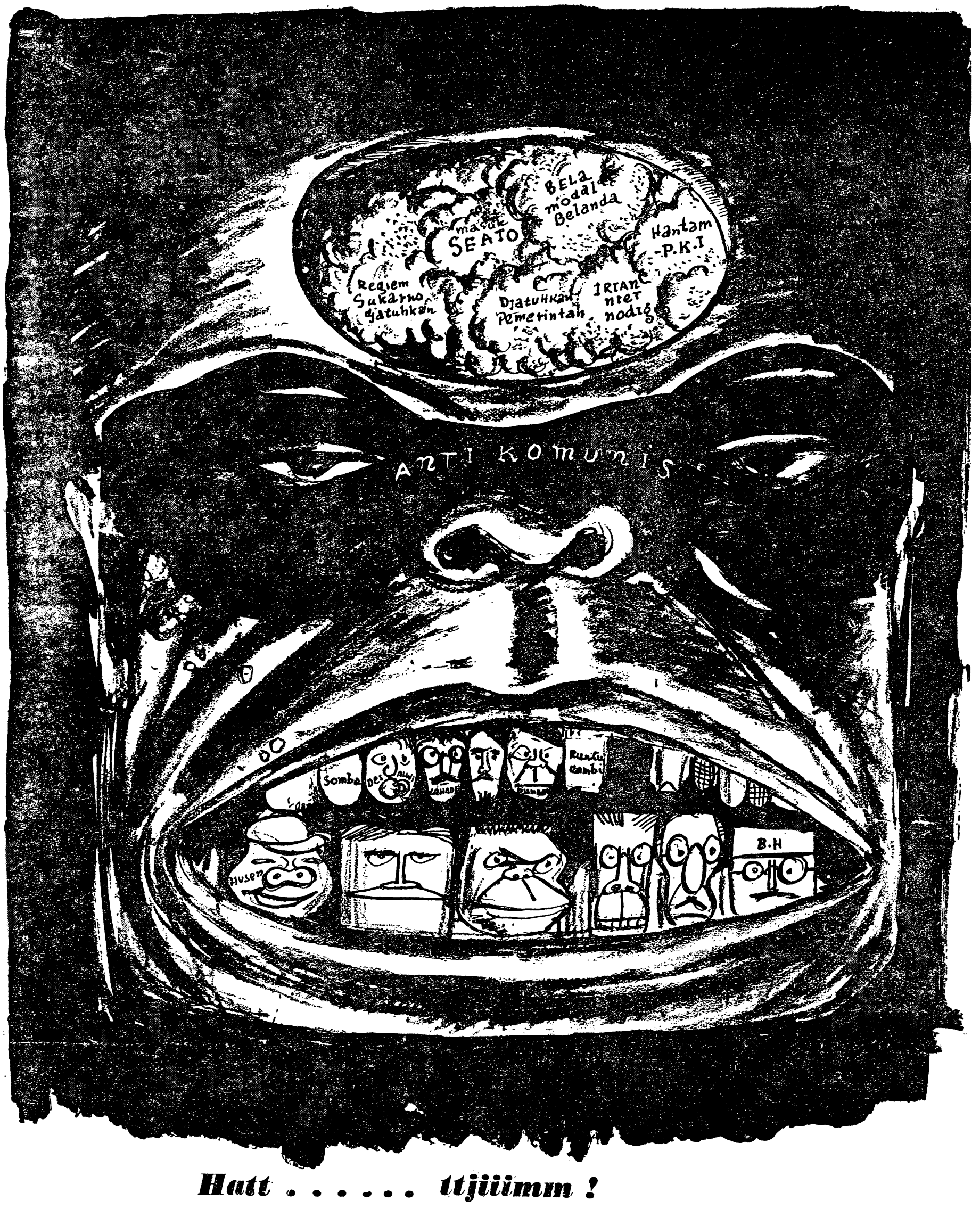



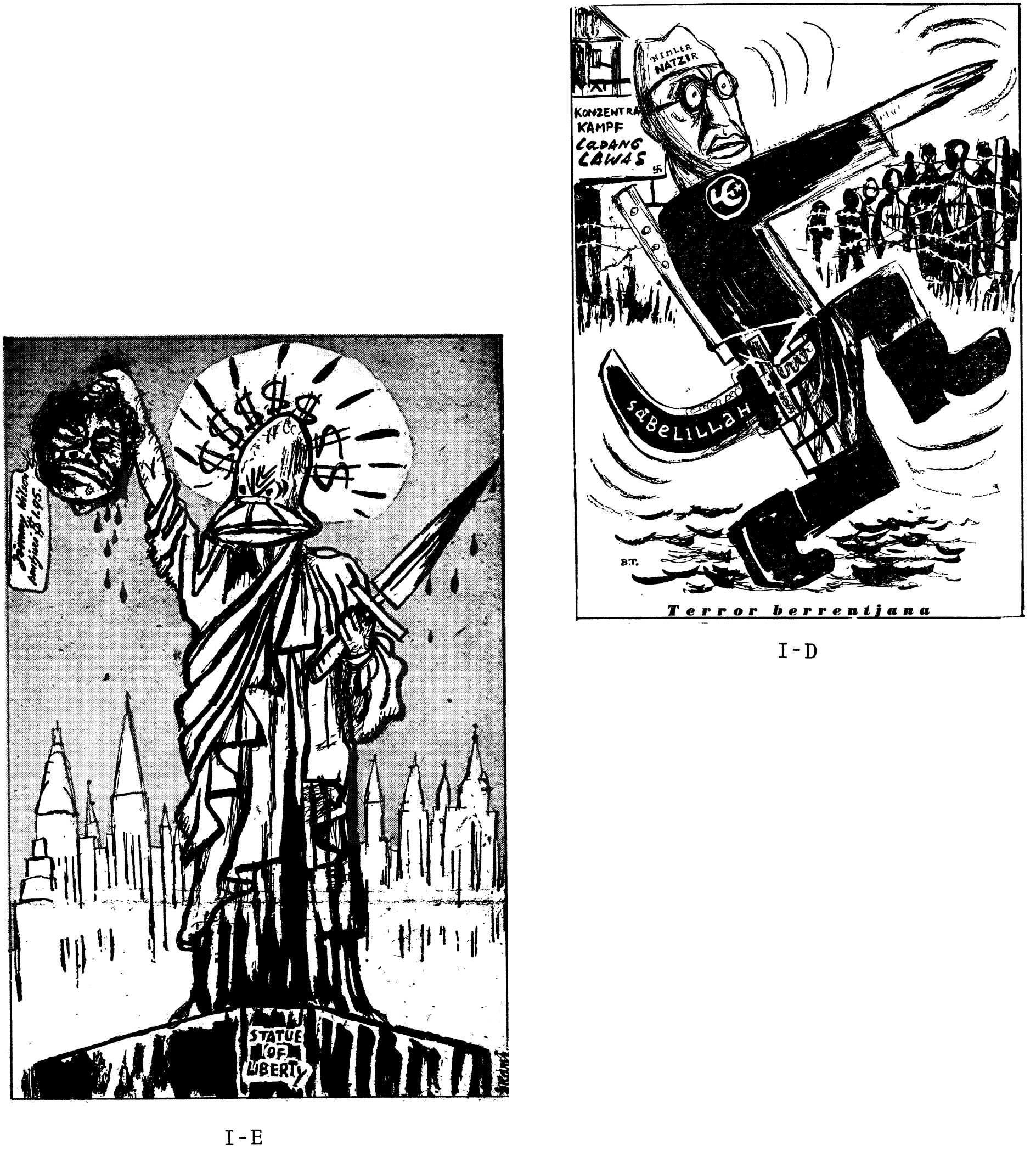


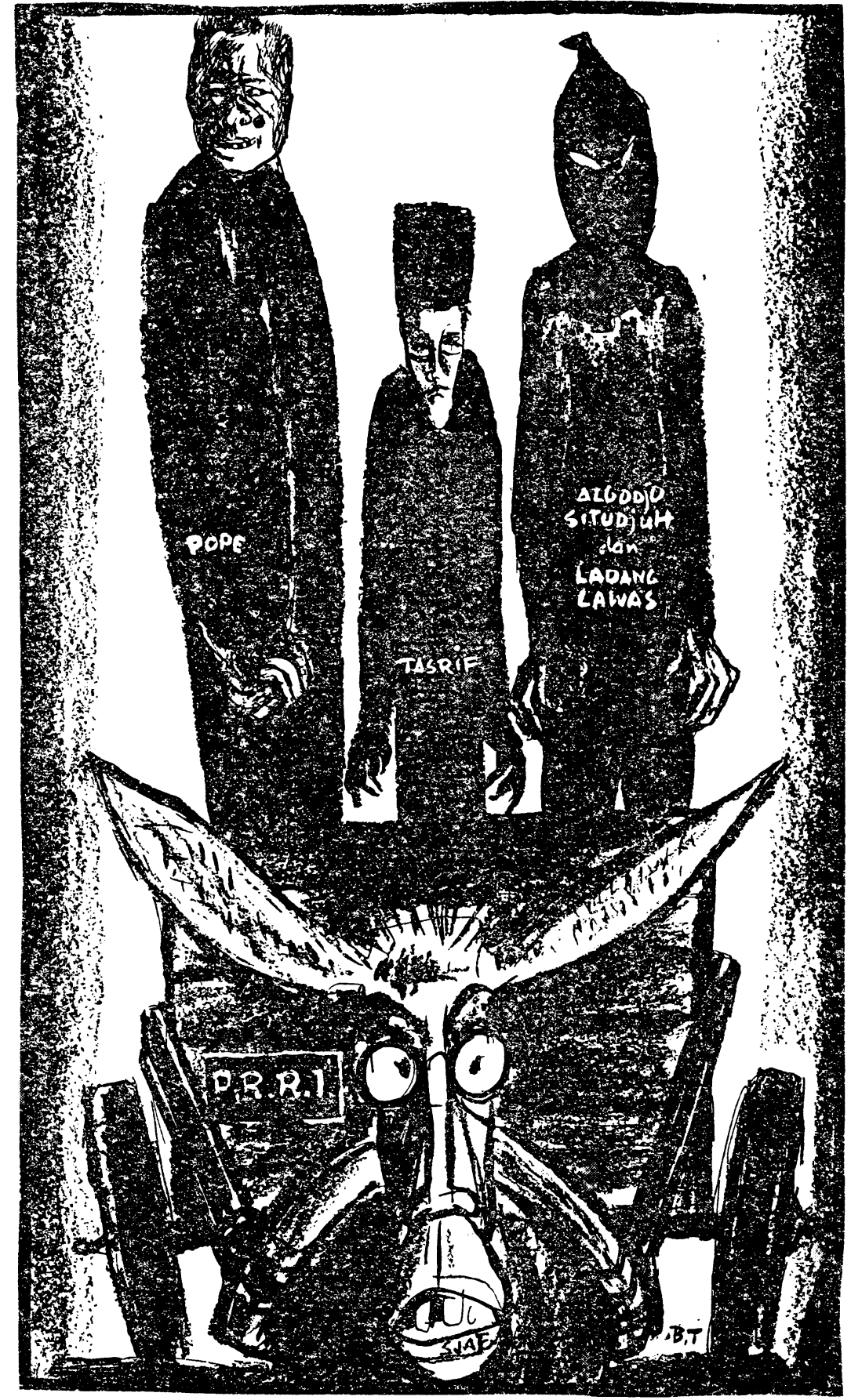

I - F

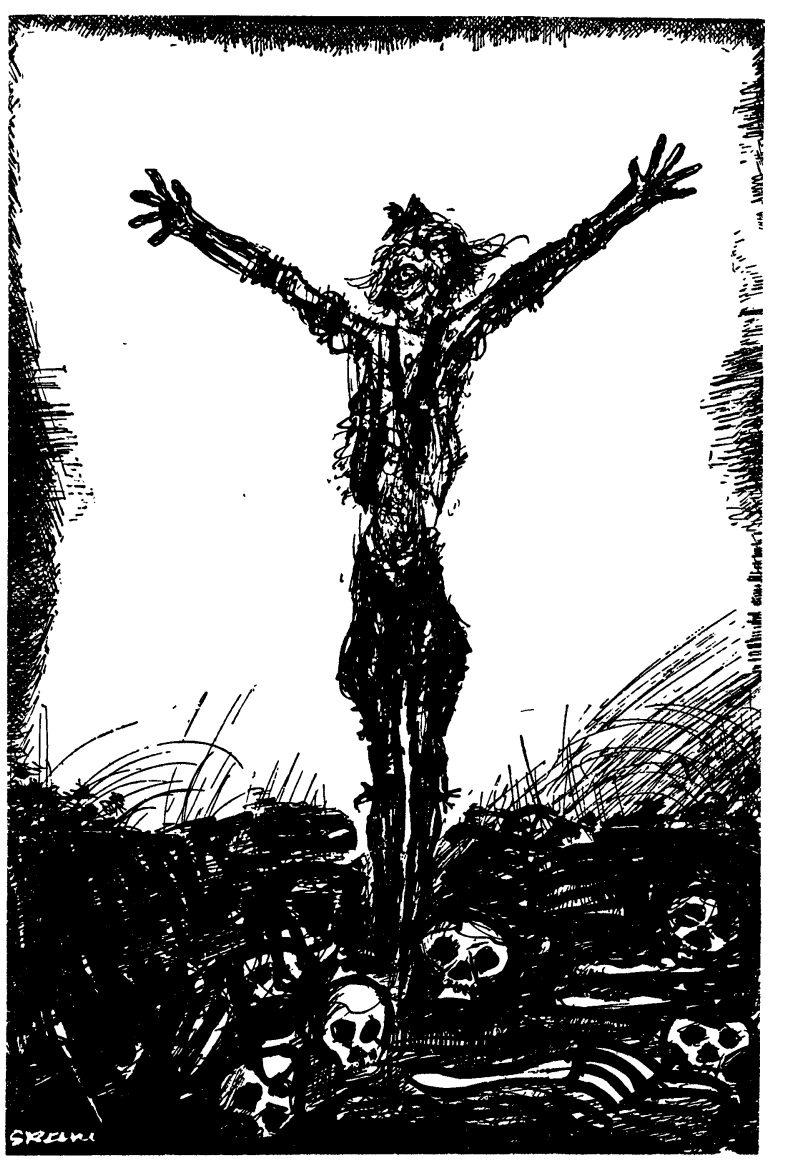

Hanglkitlah!

I - G 
Cartoon II-A. Djon Domino sings pantun (folk quatrains) at an expensive restaurant to earn money. The lyrics go:

In Krawang market work the pickpockets--

They take the train, alight at Bekasi.

The people starve, they cannot pay their debts--

Bigshots enrich themselves illegally!

With a sour expression, the company director turns and says: "That's enough! Here's a dime!" Djon accepts with a grin.

Cartoon II-B. Djon and his friends are playing cards. Friend: "Arbitrary officials . . . ?" Djon: "We crush!" Friend: "Lazy officials . . ?" Djon: "We dismiss!" Friend: "Corrupt officials . . ?" Djon: "We get friendly with, they're well-heeled!" Friend: "Shhh!"

Cartoon II-C. Djon calls on a prospective father-in-1aw. Father-in1aw: "Djon! Are you serious about Ita?" Djon: "Of course I'm serious, pak! But I need three years first to finish my studies!" Father-in-1aw: "In that case, give me a down payment of half-a-million, so I don't give her to someone else!"

Cartoon II-D. Djon and his friend watch a luxurious official limousine roar by. Djon: "Hey there, bigshot, have a thought for the fate of the people! Don't just think of kickbacks and second wives!" Friend: "How can he possibly hear you, Djon?" Djon: "Think I'm crazy? If he could hear me, he'd clout me a good one! I'm a relative (masih famizi) of his!"

Cartoon II-E. Djon and his girl friend Ida are out riding on his motor-bike. Ida: "Do you rea11y love me, Djon?" Djon: "100\%, Ida!" Ida: "Suppose I killed myself, Djon?" Djon: "I'd kill myself too!" Ida: "Suppose I sold myself, Djon?" Djon: "Then I'd be your tout so long as I got a cut!"

Cartoon II-F. Djon is teaching some children about the meaning of Sanskritized words. Djon: "Bina Marga?" First boy: "Bina means erect, build; marga means road, so Bina Marga means roadbuilder." Djon: "Bina Ria?" Second boy: "Bina means erect, make; ria means happy, so Bina Ria means something that makes you happy!"lo Djon: "Binatu?"ll Third boy: "Bina means erect; 'tu means you-know-what, so binatu means you-know-what is erect!"

While satirical or comic art is very old in Indonesia, it would be a mistake not to recognize the novelty of the cartoon form. The cartoon, as we know it, is dependent on a sophisticated printing technology as we11 as on a partly monetarized economy creating a public able and willing to purchase this type of industrial commodity. But beyond that, the cartoon appears to correspond historically to the development of a certain type of consciousness--one which conceives of politics secularly as a separate, half-autonomous realm of human interaction, and one in which mass publics share. It seems plausible

10. The reference is to the Bina Ria amusement park in Djakarta, much patronized by lovers and prostitutes.

11. Binatu (launderer) is an ordinary Malay word, not a Sanskritized honorific--but it happens to begin with Bina, and so is used here for comic effect. 

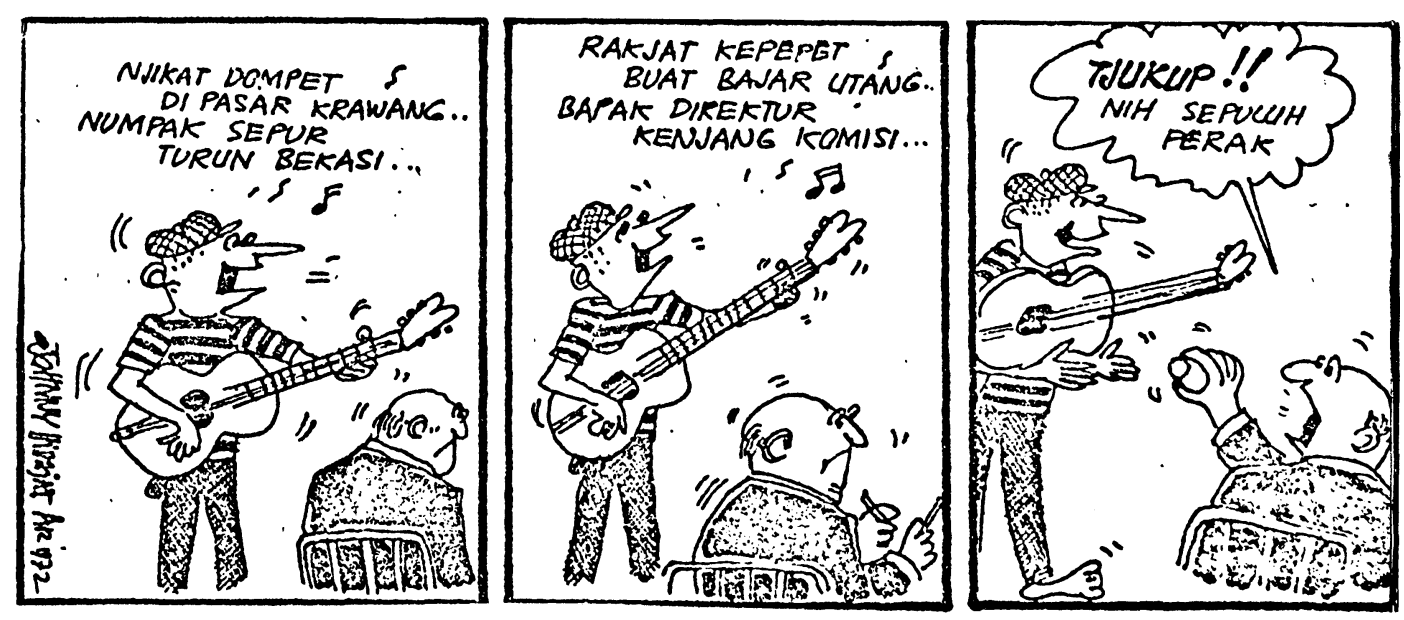

I I - A
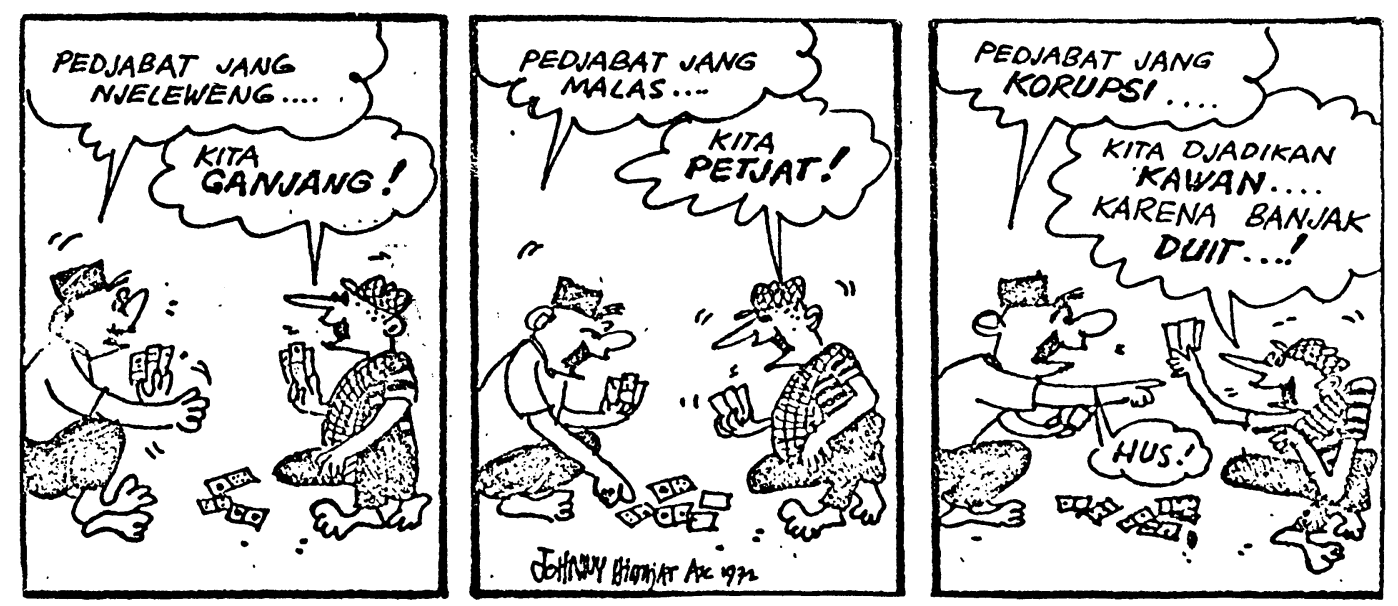

I I - B
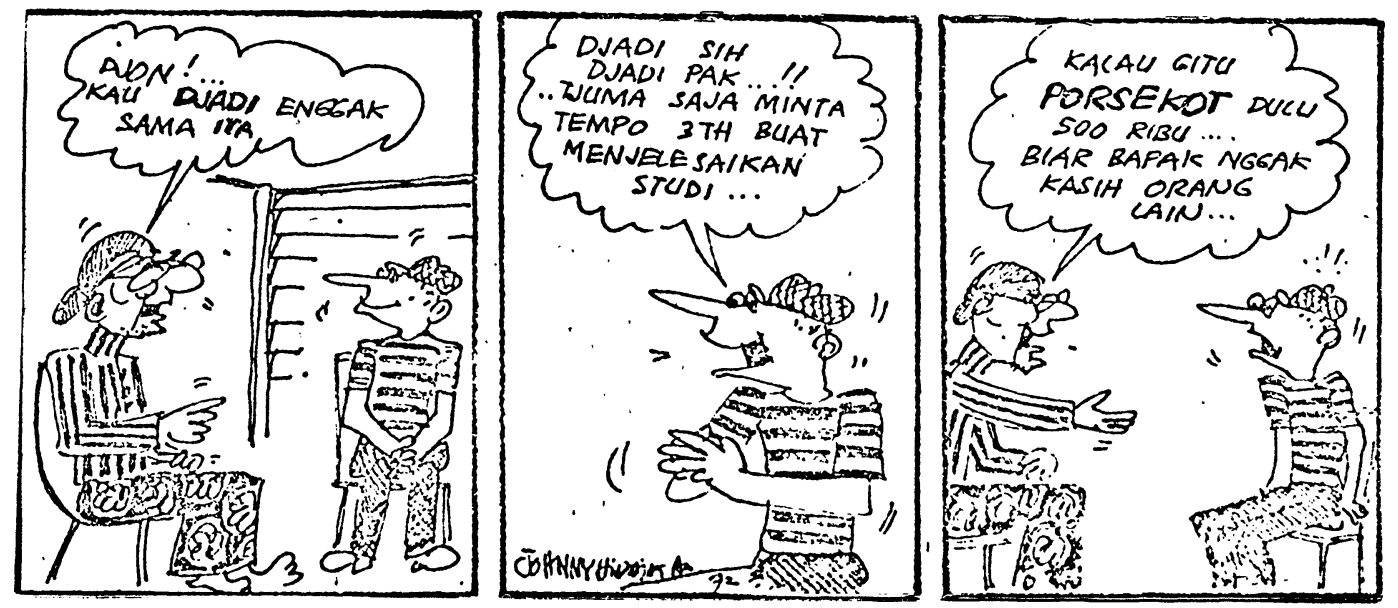

I I - C 

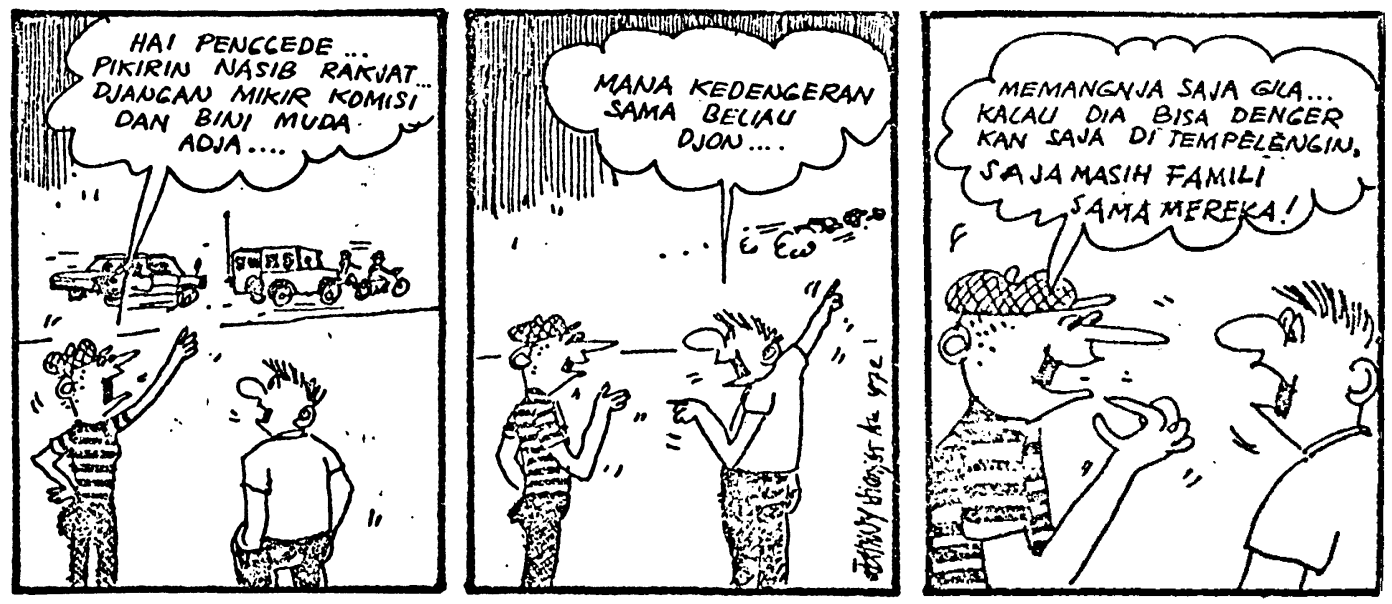

I I - D
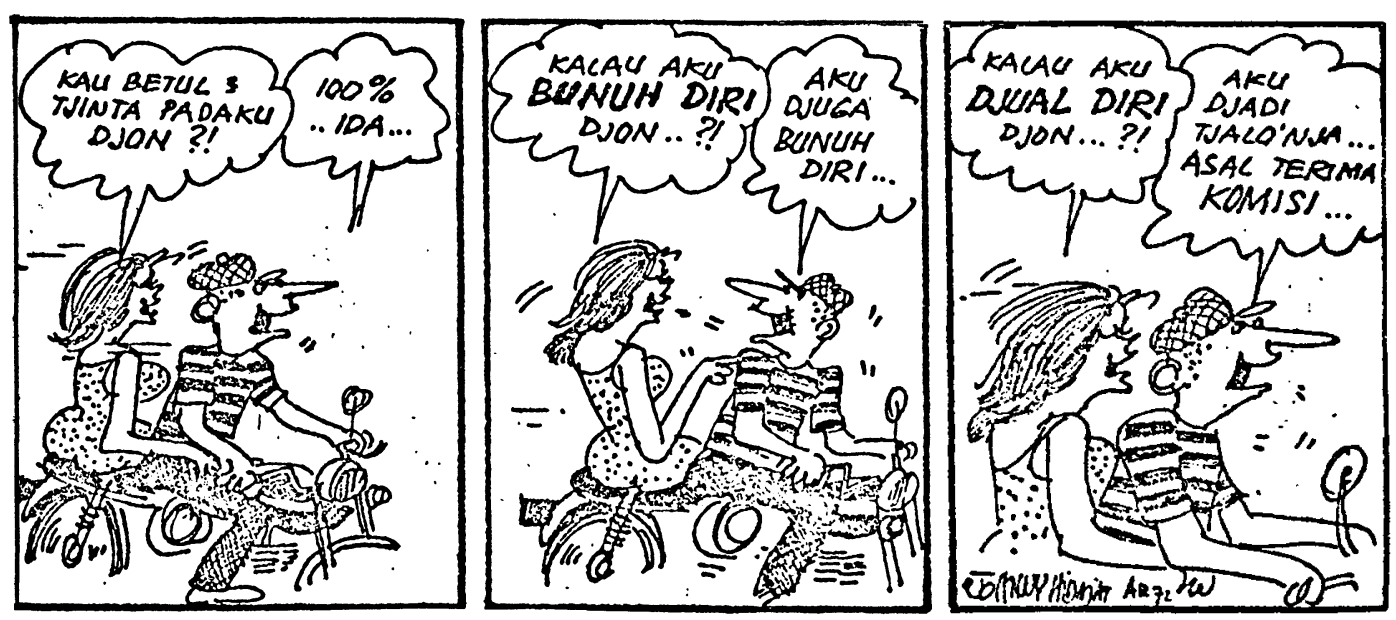

I I -E
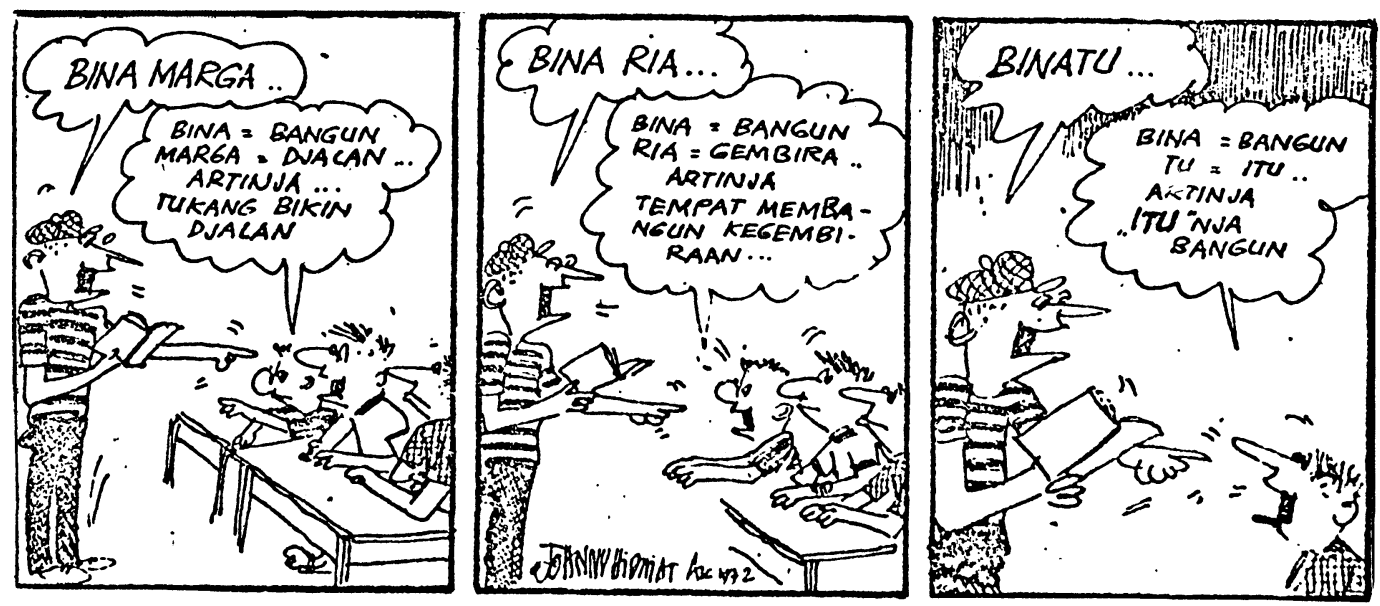

I I - F 
that the normally oppositionist aspect of the cartooning tradition derives less from the lampooning instinct than from the historical fact that mass publics had access to modern types of political communication long before they had access to power. Cartoons were a way of creating collective consciences by people without access to bureaucratic or other institutionalized forms of political control.12 In Indonesia, the conditions outlined above did not come into being until the early part of the twentieth century, and therefore, while I have no data on the dates of the first Indonesian cartoons or comic strips, it is unlikely that they appeared much earlier than the $1930^{\prime} \mathrm{s}$.

In formal terms, then, Sibarani and Hidajat have a common ancestry in the great British cartoonists of the eighteenth century, James Gillray and Thomas Rowlandson, and in the fertile caricaturists of the French Revolution, mediated through the tradition of Dutch cartooning and the later corpus of the American comic strip. ${ }^{13}$ But while this perhaps tells us something about the adoption of the cartoon-comic strip format, it tells us very little about the individual artists' personal style and message.

It would not be hard to find an indigenous ancestry for Sibarani's powerful and rough-hewn style. In the immediate past, one thinks of the cartoon and poster art that developed so rapidly under official sponsorship during the Japanese Occupation, and less officially in the subsequent national revolution. ${ }^{4}$ Further back in time, the sharply

12. This helps to account for the relative rarity and late appearance of cartoons as instruments of official political propaganda. Perhaps the best known example of this minority group is the Soviet official humor magazine Krokodil. A nice collection of Krokodil cartoons is contained in Roger Swearingen, What's so funny, comrade? (New York: Praeger, 1961).

13. For some interesting material on the history of cartooning, see Reinhold Reitberger and Wolfgang Fuchs, Comics, Anatomy of a Mass Medium (Toronto and Boston: Little, Brown and Co., 1971), especially at pp. 7, 11, 29, 174-75. Though the authors declare that "from political caricature to comic strip was but a short step," they point out that "comics have [only] existed for the last seventy-five years." They note, too, that historically the prime audience for comic strips has been the lower middle class. The first "indigenous" comic strips (i.e., not American imports) did not appear even in Europe until the 1920's, and only really flourished after World War II. The first strips to appear in Indonesian newspapers were also American imports.

14. For some examples, see various issues of Djawa Baroe; Anonymous, Marilah membela tanah air kita dengan darah daging kita! (n.p.: n.p., 1945), and Departemen Penerangan, Lukisan Revolusi, 1945-1950 (Djakarta: n.p., n.d. [1954?]). Some distinctions need to be made here, though their interpretation will be left to later in this essay. Under the Occupation, cartoons and posters were widely used, but they appeared exclusively under the aegis of the military authorities. The targets of the cartoons were typically outside society--the Dutch, the British and the Americans. During the Revolution, posters and graffiti were the most common and most popular forms of visual speech, while cartoons became a relative rarity. Of 40 newspapers and magazines from that period that $I$ have checked through, only eight carried cartoons at all; even these cartoons appeared irregularly, at rare intervals. Doubtless part of the explanation lies in technical problems caused by the shortages and disorder of those years. But the fact that the great bulk of these cartoons were printed in papers published in Dutch-occupied Djakarta, not in towns held by the Republic, suggests that the full answer lies as much in the political-cultural as in the technical realm. 


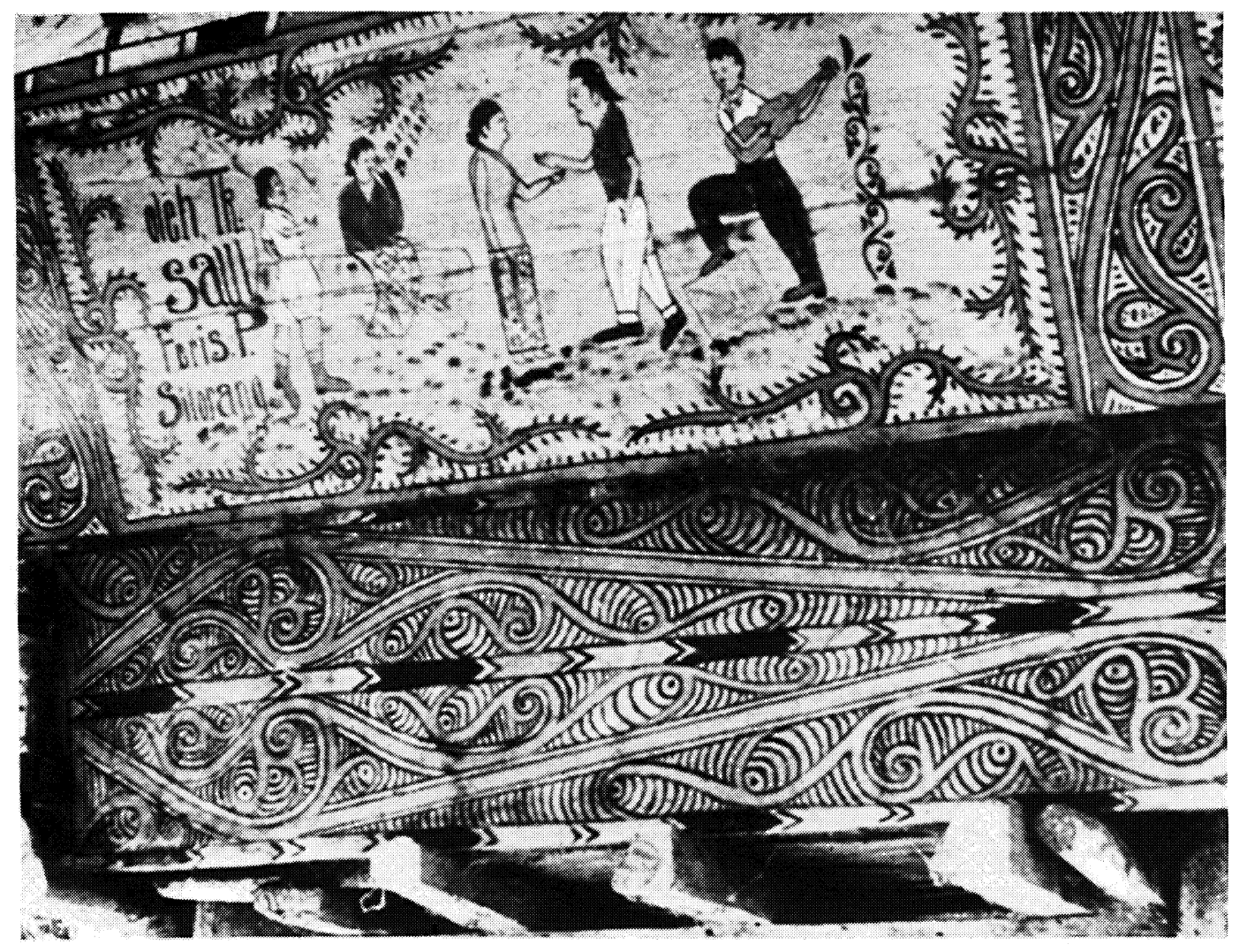

Courtship scene painted on gable of Batak house in Huta Djangga (1947). Photo: Claire Holt.

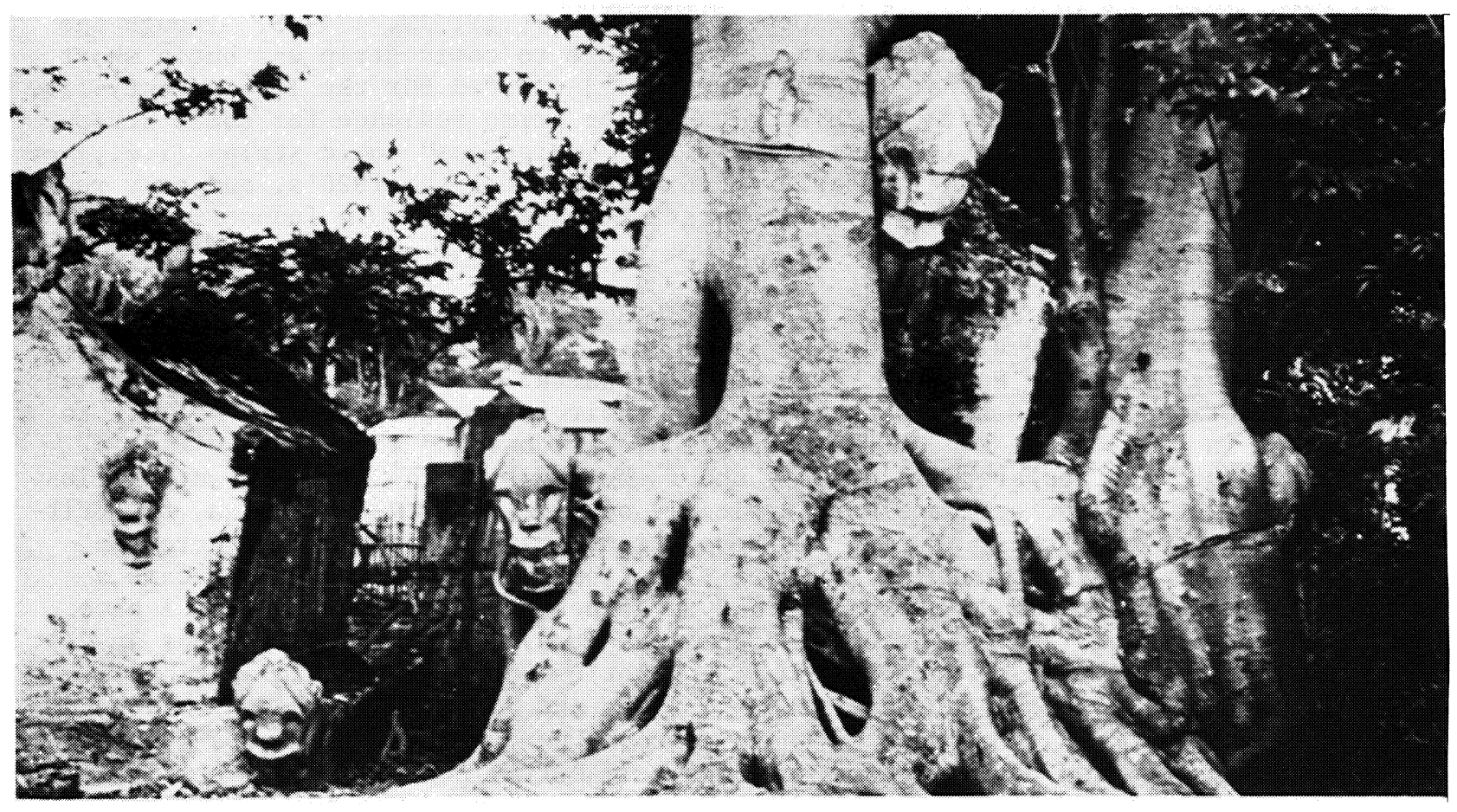

Traditional funerary sculpture, Balige. Photo: Claire Holt. 
humorous and eerily monumental art of Sibarani's Batak ancestors comes to mind. 15 For many Indonesians the Batak have a reputation for being :erem (sinister, frightening) in physiognomy and character, and Sibarani's cartoons could well be described this way. But even indigenous tradition in itself sheds little light on the historical meaning of an artist's work; to explore this more coherently we must turn to the specifics of his style.

Many of Sibarani's best cartoons, certainly his most serem, depend for their effect on a stark chiaroscuro. Executioners, embezzlers, imperialists and spies appear as sombre figures in a twilit landscape. Moral and pictorial darkness complement each other. The artist does not simply label Natsir or Tasrif a butcher, but reinforces the judgment with a simple element of design. At first sight, Sibarani seems merely to be exploiting a standard cartooning technique for "blackening" the objects of his enmity. Yet at the same time, by looking at the landscape of the cartoons, as well as the central figures, one can learn something rather different about the meaning of this lighting. Sibarani's readers lived and read his cartoons in a physical landscape drenched in sunlight, dust and color. The actions he describes and condemns took place in daylight, more or less in public, often in the rough-and-tumble of urban politics. Yet one sees none of this in his designs. So one learns that the chiaroscuro is less "political expressionism" used as a pillorying device than a means of education. Sunlight in the world and darkness within the image is a contrast which shows Sibarani's readers something about the everyday opacity of the social-political order and the reality of the forces that move it. Chiaroscuro is thus a device for political demystification.

Another key element in Sibarani's style is its iconographic density, exemplified by the conscious layering of emblems. In itself this is traditional of a certain type of editorial cartooning. 16 But it is instructive to see how Sibarani employs the device, and for what purposes. Cartoon I-D is a good example of his method. He seizes on the fortuitous assonance of Natsir and Nazi as the basis for an intricately constructed icon. 17 The point made explicitly on Natsir's cap--

15. See, for example, the varied illustrations in A. J. de Lorm and G. L. Tichelman, Beeldende Kunst der Bataks (Leiden: Brill, 1941); also G. L. Tichelman, "Toenggal Panaloean, de Bataksche Tooverstaf," Tijdschrift voor Indische Taa1-, Landen Volkenkunde, 77 (1937), pp. 611-35; and D.W.N. de Boer, Het Toba Bataksche huis (Batavia: Kolff, 1920). Though the photographs in the last item are not $\overline{\text { very }}$ good, they do include shots of the humorous wall-paintings typical of certain traditional Batak houses which the other sources neglect. Cf. the style of I-A and I-B with that of the other Sibarani cartoons.

16. The caricaturists of the French Revolution were particularly ingenious builders of elaborate cartoon emblems. See Henderson, Symbol and Satire, passim.

17. I have seen no satisfactory explanation of the contemporary Indonesian fascination with the Third Reich. In the early 1960's bookshops did a flourishing trade in cheap, lurid booklets on Nazi atrocities, espionage and terror. One finds quite frequent references to Nazism, by no means always horror-struck, in the writings of the political elite. A notable example is Sukarno, Ilmu Pengetahuan Sekadar Alat Mentjapai Sesuatu (Djakarta: Departemen Penerangan, Penerbitan Chusus No. 253, 1963). Cf. also M. 0. Parlindungan, Pongkinangolngolan Sinambela gelar Tuanku Rao, teror agama Islam Mazhab Hambali di tanah Batak 1816-1833 (Djakarta: Tandjung Pengharapan, 1964). One of the most effective 
Himmler-Natzir--is picked up in the enswastikaed Masjumi crescent moon and star, and the very shape of Natsir's goose-stepping body. The sign at the entrance to the Ladang Lawas camp identifies it with Nazism by the use of German rather than'Indonesian words; and as a final emblematic detail, instead of the "correct" ending to Konzentrationslager (concentration camp), Sibarani ingeniously substitutes, not kamp, but kampf, in reference to Hitler's Mein Kampf. In cartoon I-E, the same method is employed to dismantle the formal iconography of the Statue of Liberty and reassemble it for educational purposes. We have already observed that the torch has become a severed head, the book a bloody sword, the aura a dollar glow, the placid female face a caricature of Eisenhower. Again one finds Sibarani's characteristic use of language for iconographic point. The Indonesian words on the label attached to the head "Jimmy Wilson, pentjuri $\$ 1.95$ " stand outside the icon, acting dS an explanatory footnote. But "Statue of Liberty" remains in English, inside the icon. American "liberty" is being pilloried, not merdeka or kemerdekaan: indeed merdeka and liberty are implicitly contrasted by this device. In cartoon I-G, too, the significance of the death of left-wing militants is condensed onto the image of the crucifixion.

In all these instances the dense, meticulous iconography serves the same purpose as the chiaroscuro: by distortion and designing artifice to reveal the artificial nature of perceived, received reality, and thereby to demonstrate the really real.

A third notable element in Sibarani's style is his use of foreign (Western) languages and symbols. In some cases the purpose is clear and simple. For example, in cartoon I-C, Sibarani deliberately uses the hybrid Irian niet nodig rather than the Indonesian Irian tidak perlu or even the Dutch Nieuw-Guinea niet nodig to pillory the mestizo Dutch-mindedness of Hatta and his anti-communist associates. In other cases, the intent is more obscure. In cartoon I-F, for example, Sjafrudin is depicted as a donkey. To understand the point of the cartoon, one almost has to know the European stereotype of the donkey, and the use in Dutch and English of "ezel" or "ass" to describe stupidity and obstinacy. For the animal itself is rarely found in Indonesia, and the Indonesian word for donkey, keledai, seems only recently, under Dutch influence, to have acquired such connotations, above all in urban centers. How far is Sibarani aware of how European this cartoon's point has become? In cartoon I-E, he clearly uses the imagery of the crucifixion in a quite unselfconscious manner: Christian symbols have become fully assimilated into the contemporary style and identity of Toba Batak like himself. On the other hand, in numerous cartoons not reproduced here, Sibarani deftly uses scenes from Western Westerns playing in Djakarta movie-houses to satirize Western imperialist intrigues and menaces. One gets the strong impression that this ambiguous jousting with foreign signs and symbols shows Sibarani precisely as a "nationalist"--a man who sees the nation as an enterprise. For such men, defining what is national can only be a complex project of juxtapositions and separations between the "foreign" and the "indigenous." 18

instruments of the psychological warfare campaign waged against the left after the 1965 "coup" was the coining of the acronym Gestapu (from Gerakan Tiga Puluh September--September 30th Movement) which linked the "coup" conspirators with the atrocities of the Gestapo.

18. This was a central theme in the intellectual tradition of the prewar pergerakan. For a sophisticated treatment, see Ruth T. McVey, "Taman Siswa and the Indonesian National Awakening," Indonesia, 4 (October 1967), pp. 128-49. 
This judgment is reinforced by the "national" quality of Sibarani's work. If the landscape of his cartoons is dark and threatening, it is nonetheless a national landscape peopled by national figures. Murder is done at Ladang Lawas in rural West Sumatra, but Ladang Lawas appears as a place in the moral-political geography of Indonesia, not of Sumatra and not of the Alam Minangkabau. Eisenhower stands at the gates of both New York and Djakarta. Dulles' mishap is caused by the tree of the entire Indonesian people. Irian is "nodig." And names are named--names of men who, if they acted on provincial and local stages nonetheless drew their significance for Sibarani from the parts they played in the national drama. They are named, not simply because Sibarani wanted, and dared, to do so, but because names assign responsibility, reveal reality, and place cartoonist, reader and target in a clear relationship in political space. This in turn is linked to the presence of the cartoonist himself. He never appears in his own cartoons; it is rather as if he stood beside or behind them, proffering them to his readers with index finger pointed. Yet the pictures are suffused with his powerful imagination. The significance of this posture will only become clear, however, when contrasted with the role that Hidajat plays with respect to his cartoons.

If Hidajat's work seems so different from Sibarani's, it may be tempting to attribute this to differences in ancestry and genre. Hidajat's forms appear to derive from a comic strip tradition going back at least as far as the Japanese Occupation. The comic strip genre has its own conventions to which Hidajat strictly adheres: the strip explores situations and actions where the cartoon "summarizes" a condition.19 Rather than elaborating on space to explore meaning, the strip moves rapidly through time towards a denouement. The printed word is "in the picture" and carries the movement of the strip, only rarely performing an iconographic or emblematic function. In part, then, one can perhaps account for the rudimentary drawing, the absence of landscape, and the symbolic poverty in terms of genre conventions-though this does not tell us why the conventions are adopted in the first place. Nor do the conventions help to explain Hidajat's popularity. Even the jokes themselves, good as they usually are, do not adequately account for the strip's success. The interpreter is inclined, therefore, to turn to style and, ultimately, context.

It may be useful to start with the central figure of Hidajat's cartoons--the long-nosed, canvas-capped, T-shirted Djon Domino. The long nose, a physiognomical rarity among Indonesians, suggests at once an iconographic allusion to the long-nosed wajang clown (punakawan) Petruk. Why this particular clown figure should have been selected from the wide variety of such punakawan is a question that will be taken up later on. For the moment, what is important is that, quo punakawan, Petruk has a dual role to play. In wajang of whatever sort, the punakawan both appear as comic characters within the line of the drama, embedded in its space and time, and as mouthpieces for contemporaneous satire and criticism directed straight at the audience, so to speak at right angles to the drama and outside its space and time. 20

19. There is probably an analogy here with the relationship between editorials and podjok (corner columns) on the front pages of Indonesian newspapers.

20. This applies to both of the most popular contemporary forms of wajang--wajang wong and wajang kulit. In the older wajang kulit shadow-play, highly stylized and iconographically specialized leather puppets are deployed and vocally animated by a single puppeteer (dalang) seated behind a lighted screen. For much 


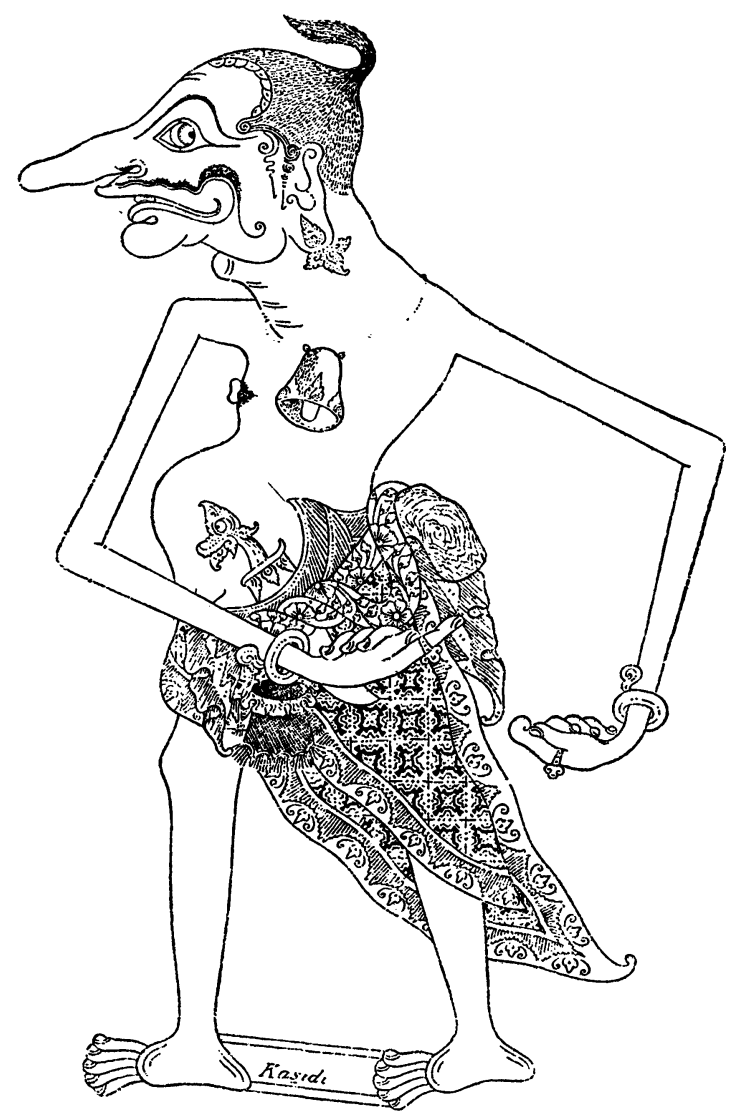

Petruk

So here one sees Petruk playing his part in the strips, but there is also, as it were, a dalang behind the paper screen or a player behind the mask. Djon Domino, as Petruk here is termed, is a rebus readily deciphered: Djon = Johnny (Hidajat) + Domino = mask, or better halfmask. Djon Domino is Hidajat behind his mask. Yet there are further ambiguities, as befits the relationship between player and mask. Djon Domino appears in the strips dressed identically (it is his iconographically conventionalized costume one observes) as: singer in a restaurant, roadside lay-about, student, motorcyclist, teacher, and relative of a high government official. These roles have no connection with each other--in "real life" they would be, in many cases, mutually exclusive. In an obvious way they are created in the service of particular jokes and satirical observations. But one notes that Djon Domino not only has no clearcut social role or status, but that he has no friends or enemies, no family or identifiable associates, unlike many stock characters in American strips. Only his mask Iinks Djon Domino's protean and elusive appearances. It becomes evident that the mask mediates its creator's dalang consciousness.

of the audience the dalang is invisible, yet his personal presence is manifested through all the puppets, above all through the sallies of the punakawan. In the newer wajang wong, a stage drama in which the older puppet-roles are taken by human actors, the punakawan-players wear heavily stylized facial make-up modeled on wajang kulit iconography and on the wooden masks of the largely obsolescent topeng dance drama. From behind these "masks" the players--very often the stars of the troupe--direct their sardonic, anachronistic asides to the delighted audience. 
This leads directly to another half-hidden element of order and continuity in the strips. Almost all of them reveal a symmetrical relationship between Djon Domino and the "target" of his creator's satire. Thus, in cartoon II-A, Djon plays cadger-petty blackmailer to the embezzling director; in II-B he is would-be accomplice to a corrupt official; in II-C, he is the loser in a cynical game of wits with a prospective father-in-law; in II-D, he is "masih famili" with the opulent minister; in II-E, he plays pimp to his girl-friend's prostitute; in II-F, he pretends shock while egging on the sexually precocious and knowing children. In effect, in almost every strip, Djon appears as a less successful version of the target pilloried, as an accomplice, a1most as a hanger-on. The key phrase is "masih famili"--which implies both a kin relationship, but also a subordinate or dependent form of that relationship. This in turn is connected to both the traditional and contemporary meanings of punakawanship.

The punakawan in the wajang drama are servants, followers and dependents; they follow where their satria or other masters lead them. They are both closely intimate with their masters (as it were "masih famili"), and yet permanently consigned to their subordination. They both know their superiors completely, and yet are destined to continue serving them. Their jokes are often sly digs at their masters' pretensions, but these digs are without subversive intent: the nature of the wajang world--a world of masters and servants--is not called into question. As we have seen, however, the punakawan also play a direct role vis-à-vis the audience. In traditional milieux, it is precisely subordinate elements among the audience to whom they "speak" and who appreciate "them" the most: servants, children, women. Indeed, responding to the jokes at all involves, for any member of the audience, an identification, if only temporary, with the subordinate and dominated. Thus, in the performance of wajang, a complex net of intimacies, dependencies, and solidarities is created. And it is the punakawan's iconography that 1 inks them all. Hidajat's domino serves largely the same function. Yet there is one key difference from the wajang world: in even modern forms of the ancient drama, subordination is not complicity. The satria may be laughed at--at the appropriate time--but his moral universe is separate, autonomous, and recognized by punakawan and audiences as such. 21 The satria is a different order of man, not just a man of higher power and status. The punakawan are not and cannot be satria. When they on occasion try, the result is chaos and anarchy. The best-known play (Zakon) on this theme is Petruk Dadi Ratu (Petruk Becomes King), a wild farce in which Petruk "masks" himself as a king, holds temporary sway, causes vast comic disorder, and is finally "unmasked" (resumes his mask)--at which point the drama closes in renewed serenity and order. But the words Petruk Dadi Ratu have become in modern times a proverbial commonplace to describe real social and political conditions of disorder, corruption and sinister farce. 22 One might be inclined to view Hidajat's strips merely as a

21. See the discussion of the autonomous "status" moralities of Javanese tradition in my Tolerance and the Mythology of the Javanese (Ithaca, N.Y.: Corne11 Modern Indonesia Project, 1965).

22. There are comparable lakon about other punakawan becoming ratu--all in the same thematic vein. But none begins to have the popularity of Petruk's temporary elevation. One suspects that the answer to the question of why Hidajat picked Petruk as the model for Djon Domino lies precisely in his peculiar proverbial association with disorder and reversal. 
simple restatement of this theme: each satirized authority figure that appears could be seen as a Petruk playing a role that is not in him. But a closer look at the universe of the cartoons suggests that their theme may rather be Ratu Dadi Petruk, an idea inconceivable in the traditional world. Moral statuses are indistinct, everyone is a clown, and subordinate and master are 1 inked not in complementarity but complicity. Petruk is not unmasked in each denouement, rather it is the "ratu." 23

Another stylistic element in Hidajat's strips which is related both to the Javanese past and the Indonesian present is the use of obscenity; again the contrast with Sibarani is instructive. Many of Hidajat's cartoons are sexually explicit in a manner inconceivable a few years before. In part this reflects the fact that in contemporary Djakarta ex and sexual jokes are much more publicly acceptable than hitherto. The nightclub and the "massage parlor" are well-established institutions of metropolitan life. In Sukarno's day, the one arena where sex and sexual jokes were publicly permissible was in the traditional theater, whether wajang, ludruk or ketoprak. In wajang, at least, they were above all the province of the punakawan.24 It is therefore not surprising, if we accept $\mathrm{Dj}$ on Domino as Petruk, to find Hidajat's strips a natural outlet for such jokes. But the style of the jokes and the context in which they are made suggest new meanings for such humor. One of the odd, yet logical aspects of sexuality in wajang is its rigid social stratification. Though sexual gossip in traditionalist areas of Java focuses continually on cross-class sex (masters sleeping with servants, aristocrats with prostitutes, officials with actors), on stage sexual relations are confined within status groups--or at least the servant (punakawan)-master (satria) separation is rigidly maintained. Aristocrats mate with aristocrats, servants with servants. Demons and giants are often shown lusting after aristocratic women, to the audience's great amusement, but with a few very special exceptions, they never succeed in getting them. This sexual invulnerability is an important element in the prestige of

23. It would be interesting to learn more about the way in which the phrase Petruk Dadi Ratu began to acquire new political meanings. Traditional usage refers to a temporary period of disorder, after which Petruk and Ratu return to welldefined complementary roles and statuses. Petruk is well and good--in his place. During the Revolution, one finds instances of a sharp shift in meaning. In Penghela Rakjat, May 9, 1947, for example, the pro-Dutch Sundanese collaborator Kartalegawa is denounced as a Petruk Dadi Ratu. But now the implications are that there is no correct stable role to which Kartalegawa could return. He can not be a true Petruk in the old sense. Nor can Kartalegawa become a real ratu either. Ratu-ship has lost its meaning, become hollowed out: it is an empty title conferred as a reward for puppetry and collaboration. A further irony is that everyone knows that Kartalegawa in fact comes from the Sundanese upper (as it were satria) class from which traditional ratu were drawn. So we have a ratu who is really a punakawan but who is pretending to be a ratu. The nexus with traditional usage lies only in the continuity of the idea of disorder, which now, however, is sinister rather than comic. In Hidajat's cartoon world the implications of the Penghela Rakjat article have been pushed even further. The Petruk have multiplied to become the permanent norm rather than the temporary and pilloried exception. There are no ratu left or possible. So tragedy again becomes farce.

24. This has been slowly changing, to the disgust of some traditionalists, particularly in the commercial wajang wong. One finds satria-class women such as Banowati and Srikandi on occasion engaged in sexual banter and risque jokes. 
the satria group, both in itself, and because in some respects it is a sign of self-control and thus of power. 25 In Hidajat's strips, by contrast, no one is invulnerable. In cartoon II-C, sex is a matter of commercial bargaining between $D j o n$ and his prospective father-in-1aw; in II-D, Djon and Ida are at once lovers and pimp-and-whore-in-themaking; in II-F, teacher Djon eggs on his pupils to answer questions with sexual repartee. It seems clear that sex is being used here not to make separations, or to show the complementarity of opposites, but to reveal vulnerabilities and complicities. Lovers, teachers and fathers-in-law are "just like everyone else." Gossip has become form.

Sex as such is largely a'sent from Sibarani's cartoons, but he uses obscenity for his own very different purposes. Cartoon I-B is a good example of this. It has none of Sibarani's typical chiaroscuro, perhaps because the artist is here dealing not with the nature of particular men or specific events, but rather with a basic social condition. The plain pen-lines have almost the character of a diagram or equation rather than an emblem or icon. The second half of the cartoon's theme is well described by New York Times correspondent James Sterba as follows:

The people in the kampong ... along the canal . . make their living by picking through the trash bins of the wealthy residents of Menteng, Jakarta's prosperous residential section, which begins on the other side of the railroad tracks. Everything of value is taken from the bins, mostly at night or in the early morning hours, just after the trash is thrown away by maids and houseboys. The salvage is carted in baskets back to the canal for sorting and sale. Most of the dirt-floor shacks are made of cardboard picked from trash. Five soft-drink or beer cans are worth a penny. Broken glass and broken dishes bring a cent a kilogram . . . as do old bones. Assorted broken plastic sells for four cents a kilogram. Unbroken bottles, all reusable, can bring from half a cent to a nickel, depending on the size and color; clear white glass is worth more than green or brown. A quart beer bottle, a small treasure, is worth a nickel. An average trash picker makes about 100 Rupiahs, or 25 cents a day. . .26

The first half depicts a symmetrical relationship between powerful foreign capitalists (wealthy foreigners in general) and a dependent, parasitic Indonesian urban middle class. The metaphor of coprophagy is used to bring out the humiliation Sibarani saw in the political and economic relationships prevailing in Indonesia at the time. Obscenity is a way of talking about domination and subordination. Thus, whereas Hidajat uses sexual imagery to describe intimacy and complicity, Sibarani employs excrement as a device to depict separation and degradation. (The foreign capitalists are not complicit and "eat no shit.")

Lastly, the question of locale. There is no landscape in Hidajat's pictures. The empty white space recalls the cotton kelip (screen) against which the wajang lakon are played out. Nonetheless, just as the kelir encloses and delimits a world, the universe of

25. For some comments on the relationship between Javanese views of power and sexuality, see my "The Idea of Power in Javanese Culture," in Claire Holt et al., eds., Culture and Politics in Indonesia (Ithaca, N.Y.: Cornell University Press, 1972), pp. 9-10, 27.

26. New York Times, March 20, 1973. 
wajang, so Hidajat's strips define a particular milieu, that of Djakarta in the early 1970's. This is not 01d Djakarta, the colonial city whose Indonesian population was largely composed of pious Moslem orang Betawi, but the new city that grew up after independence, dominated by migrants from a11 over Indonesia, but particularly from the Javanese hinterland. Language and costume make this clear. The speech in Hidajat's balloons is bahasa Djakarta, but laced with the Javanisms that the flood of migrants brought to the old metropolitan argot. Djon Domino's prospective father-in-law, with his surdjan (Zurik jacket), djarik (wrap-around skirt) and particularly his "egg"-tailed blangkon (headcloth) is unmistakably from Jogjakarta, yet he speaks in the same bahasa Djakarta as Djon himself. This points up one of the oddest aspects of Hidajat's strips--their linguistic homogeneity. Whereas Sibarani uses different languages quite self-consciously to build his iconography, and to talk in different ways about the national project, Hidajat is consistently monoglot--foreign words almost never appear and all parties use the same "level" of language, the ngoko of bahasa Djakarta. Why this should be so is not altogether clear. It could be argued that Hidajat, a younger man than Sibarani, grew to maturity within what Hildred Geertz has called the "metropolitan superculture of Indonesia," 27 and that accordingly for him language is simply less problematic and political a matter than it was for Sibarani.28 Or, in different words, that national-ness for Hidajat is no longer a selfconscious project but a received reality. While this may well be true, it also seems possible to think of the bahasa Djakarta in the strip as being analogous to the sex. Both are devices for talking about the contemporary relationship between ruler and ruled (or at least a certain segment of the ruled). Just as no one is sexually invulnerable, so no one is linguistically "secure." Like sexual innuendo, resolute use of the vulgar and familiar bahasa Djakarta points to an acknowledgment of power combined with a refusal of any moral status. This in turn ties in with something I shall return. to at the end of this article--why it is that, though Hidajat's Djakarta is being deluged with foreign influences (far more than that of Sibarani), and foreigners are in constant contact with Djon Domino's world of prostitutes, cabdrivers, hawkers, students and so forth, they are so absolutely excluded from the cartoons.

27. See Hildred Geertz, "Indonesian Cultures and Communities," in Ruth T. McVey, ed., Indonesia, revised edition (New Haven: HRAF Press, 1967), pp. 35-37. Mrs. Geertz writes: "The Indonesian metropolitan superculture is still in the process of formation, and is at most only two or three generations old. . . . It is in the areas of political ideology, artistic styles, and material culture that the content of the metropolitan superculture has been most elaborated. The foremost characteristic of the superculture is the colloquial everyday use of the Indonesian language. . . . The prime external symbols of adherence to the superculture are the acquisition of higher education, facility with foreign languages, travel experience abroad, and Western luxury goods such as automobiles. . . It is the intellectual and political elite and the wealthy of the great cities who are bearers of the full metropolitan superculture."

28. For a different type of analysis of the cultural linguistic movement to which Mrs. Geert $z$ is referring, see my "Languages," especially pp. 105-16. 


\section{Monuments}

In the days of Sukarno's ascendancy under Guided Democracy, Indonesia saw a great deal of monumental construction. Visitors to Djakarta since the early $1960^{\prime} \mathrm{s}$ would find it difficult to overlook the National Monument, the Freedom Monument, the Liberation of West Irian Monument, the Gelora stadium, the Istiqlal Mosque, and other more utilitarian structures which have come to dominate the visual skyline of the city's center. It would be an error, however, to imagine that monument-building was a peculiarity of the Sukarno years. As we sha11 see, the New Order has in some ways been even more monument-minded, though the type and style of the monuments have changed, and their location is more widely dispersed. While the political intent of Sukarno's constructions has often been noted by journalists and scho1ars, analysis has rarely gone further than formulations of the type: " $X$ was a prestige project, designed to impress Indonesians and foreigners with Sukarno's domestic and international political successes" or "Y was essentially a monument symbolizing Indonesia's new-found selfconfidence [or lack of confidence]." In effect, the monuments have been treated as manipulative devices or as psychological "symptoms": either way, the approach has been purely diagnostic. Few observers have recognized that monuments are a type of speech, or tried to discern concretely what is being said, why form and content are specifically what they are.

It may be useful to begin a discussion of monumental styles by drawing a schematic contrast between the periods of Guided Democracy and the New Order--in part because of the very different politics of the two periods, but also because certain themes quite apparent in New Order building were there in embryo under the previous regime, and these themes have something to do with the longer-term transformation of "Indonesian political thinking." In what follows I will be discussing "above all non-utilitarian monuments, i.e., those in which iconography clearly prevails over functionality.

It is a peculiarity of monuments of this type that, by and large, they face two ways in time. Normally they commemorate events or experiences in the past, but, at the same time, they are intended, in their all-weather durability, for future posterity. Much less than other forms of political communication are they tied to particular contexts and audiences. Most are expected to outlive their constructors, and so partly take on the aspect of a bequest or testament. At the same time, their durability gives their constructor relatively low control over what they "mean" in society. Indonesians will see some of Sukarno's monuments long after they have stopped reading his speeches, but what they will see in them Sukarno had little power to determine. Nonetheless, it is useful to think about monuments as ways of mediating between particular types of pasts and futures.

Two of the best-known monuments of the Sukarno era stand in the center of Djakarta: the Liberation of West Irian Monument in Lapangan Banteng, and the National Monument in Medan Merdeka. The first consists of a rugged human figure, standing on top of two vertical concrete steles, his arms flung up to the sky, and broken chains at his feet. The style of the figure is "realist," or better "Jogja socialist realist." 29 The National Monument is conceived more abstractly: a

29. For a good discussion of modern art schools in Indonesia, see Claire Holt, Art in Indonesia, Continuities and Change (Ithaca, N.Y.: Cornell University Press, 1967), Chapter 9 . 


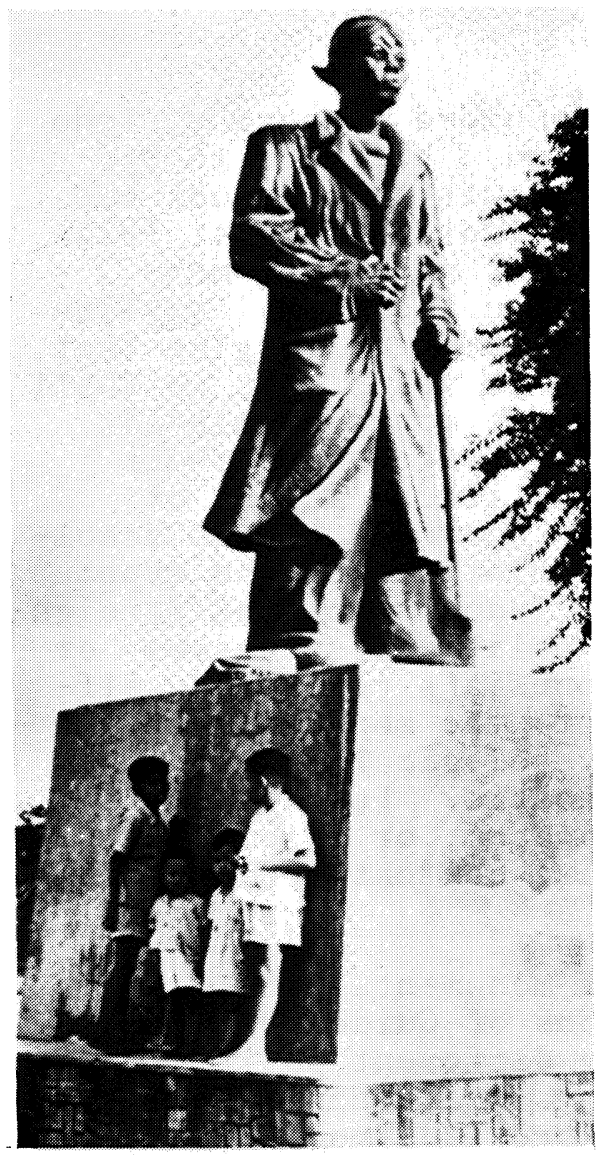

General Sudirman.

Photo: Claire Holt

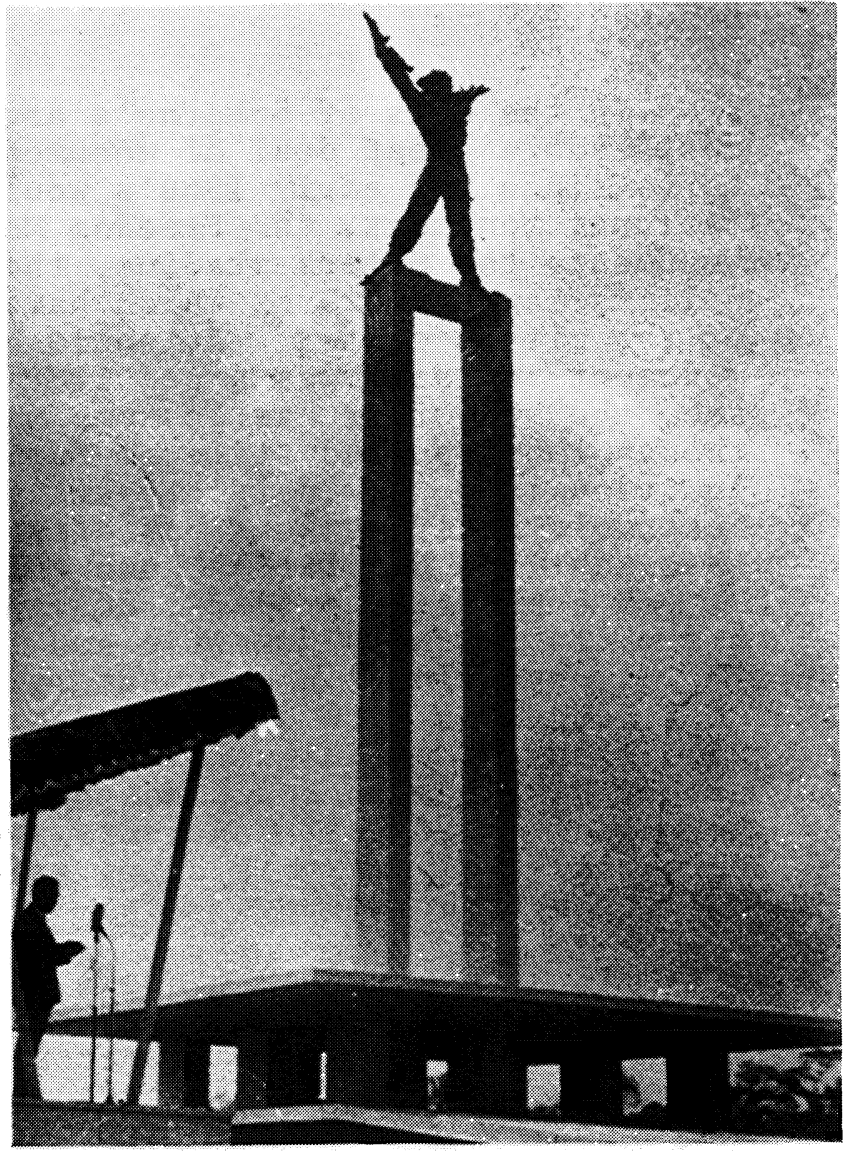

Irian Barat Monument

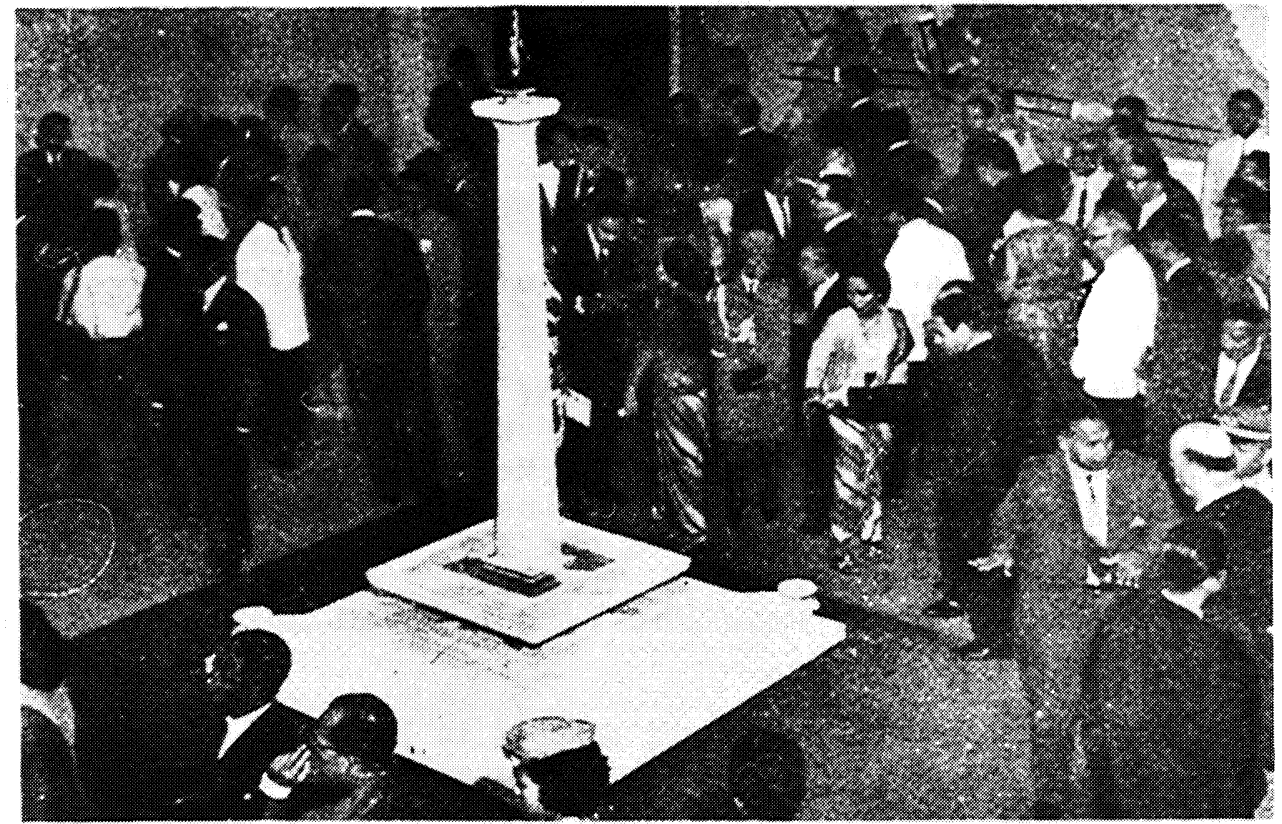

Mock-up of National Monument 
tall stele crowned with a golden "flame" implanted in a flat-topped base large enough to contain within it chambers for the exhibition of patriotic reliefs and tableaux as well as national pusaka of certain types. The style of the Irian Monument is both modern and, as it were, "individual." It does not obviously evoke traditional Indonesian monumental art, and the form itse1f has evidently been created for a specific historical event. The statue symbolizes directly the liberation of the Irianese from Dutch colonial rule.30 Innovation and uniqueness remind the observer of the completion of an historic task--the unification of Indonesia under Indonesian rule--launched more than half a century before. Paradoxically, therefore, novelty of form points to the achievements of the past, but at the same time commemorates a project in which the constructor and his audience all in different ways participated directly, and thus points back to the future that they shared. Even if the modern statuary is mediocre, is nonetheless is a traditional monument in the sense that it is part of the real movement of Indonesian history, not a gloss upon it. ${ }^{3}$ (We shall explore the significance of this below.)

The National Monument is more ambiguous in character, and seems to foreshadow the monuments of the New Order in some interesting respects. In terms of formal style, the monument is mestizo: it borrows from the conventions of European patriotic obelisks, while at the same time evoking the lingga-yoni of ancient Javanese art. ${ }^{32}$ The 1 inggayoni motif was quite self-consciously chosen (Sukarno reportedly joked that the monument testified both to his own and Indonesia's inexhaustible virility): it was to be "national" because it was "traditional," not, as it were, "traditional" because it was "national." The monument in fact commemorates no specific event or achievement, but is rather in the nature of a summary of or commentary on the Indonesian past. Thus, the implicit movement of the form lies in the opposite direction to that of the Irian. Monument: conventional iconography appears to use the past to express Indonesia's triumphant modernity, but in fact it points backwards in that it is no more than a gloss on that past. To put it another way, whereas the ancient Javanese built lingga-yoni monuments because, as it were, they meant something in themselves (Kempers says they stood for "the Duality.. . which is dissolved into the Supreme Unity or Totality of all existence") and were part of the ancient present and future, Sukarno built his to show that the present Indonesia is connected to the past. The National Monument is thus less a part of tradition than a way of claiming it. The linggayoni in Medan Merdeka means nothing in itself, but is rather a sign for "continuity."

30. It is thus analogous to the fine statue of General Sudirman on Malioboro in Jogjakarta, which commemorates the last heroic years of his life as guerrilla leader.

31. In this respect it resembles the first national monument of the new-born Republic: the stele-cum-plaque put up in 1946 at Pegangsaan Timur 56, Djakarta, to commemorate the Proclamation of Independence a year earlier. (For a picture with accompanying article, see Ra'jat, August 19-20, 1946.) What is noticeable about both monuments is that their erection followed very closely in time on the event or circumstance that they commemorated. The contrast is striking with the monuments discussed below.

32. Compare, for example, A. J. Bernet Kempers, Ancient Indonesian Art (Amsterdam: van der Peet, 1959), p. 19 and Plate 166; and Holt, Art in Indonesia, Plate 18. 


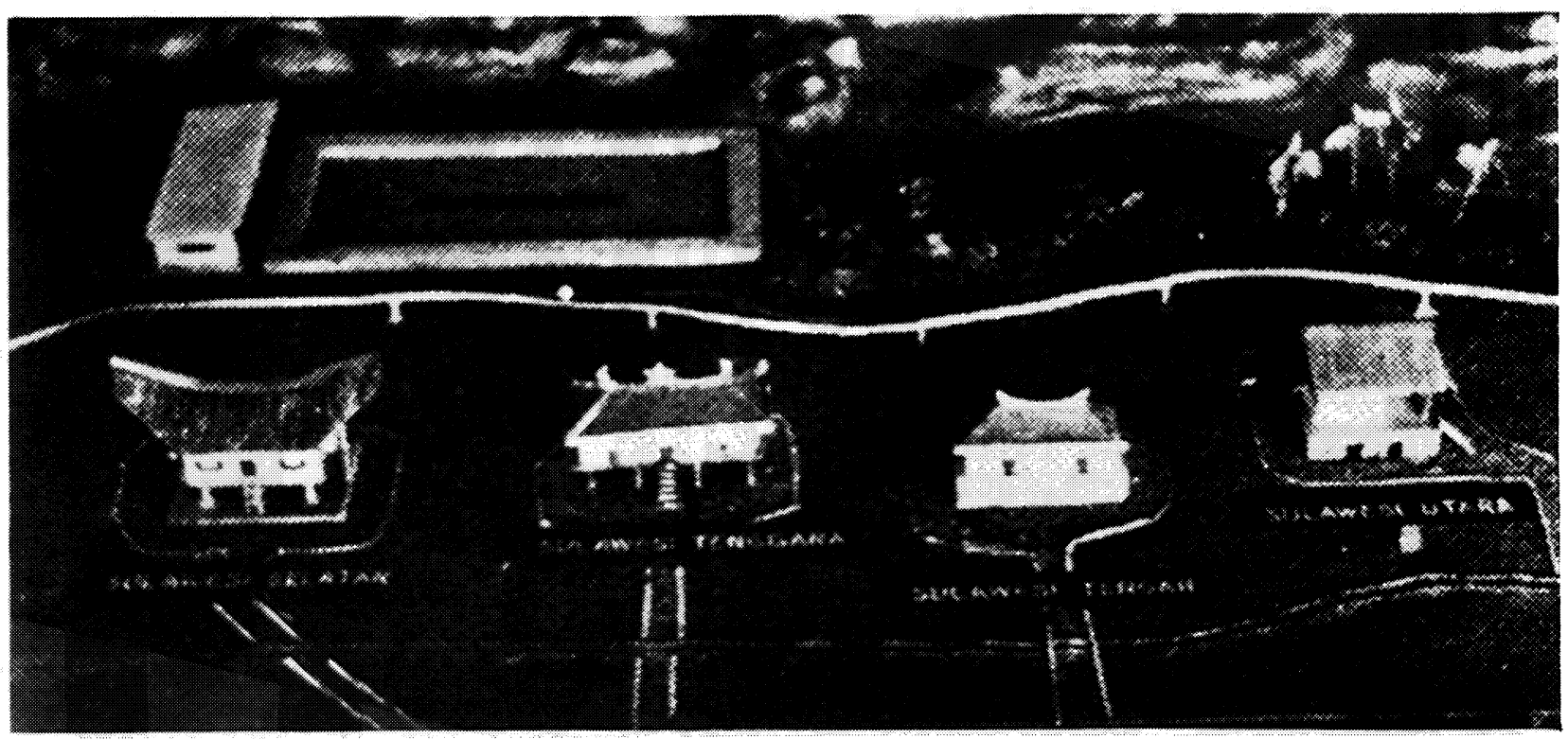

(Tempo, November 27,1971 )

The monuments of the New Order bring out this pattern far more clearly. Oddly enough, the most celebrated New Order monument is still unbuilt: the so-called Projek Miniatur Indonesia Indah (Beautiful Indonesia in Miniature Project), popularly known as "Mini," which is to be constructed by the Our Hope Foundation (Jajasan Harapan Kita) chaired by President Suharto's wife. Whether the initial inspiration for the project came from Mrs. Suharto's March 1970 visit to Bangkok (where an analogous project [Timland] has been completed), 33 from Disneyland, or from the contemporary vogue for beautification work by presidential wives, as described to the public in the fall of 1971 Mini was to consist of: a fenced-in 100-hectare compound containing an eight-hectare artificial lake in which little islands representing the archipelago would be placed; in addition, there would be 26 adat (traditional) houses from each of Indonesia's 26 provinces (one hectare apiece); a 1000-room tourist hotel; an imitation waterfall; a cablecar; a revolving and an outdoor theater, and so forth. 34 The adat houses would contain appropriate handicrafts from the various regions."

For reasons which need not detain us here, Mini was unpopular from the start, causing a wave of student protests in a number of cities and some strongly critical editorials in the metropolitan press. 35 The

33. Tempo, June 5, 1971.

34. Tempo, November 27, 1971.

35. As early as May 1971, some of the people who had been, as it were, evicted to make room for the project, complained to the Lembaga Bantuan Hukum (Legal Aid Institute) that they were being compelled to sell their land to Harapan Kita at prices less than half the real market value, and that the land they were being 
controversy, however, did have the effect of goading the project's sponsors into clarifying the purposes of their undertaking. Speaking to the Working Conference of Provincia1 Governors on December 1, 1971, Mrs. Suharto urged them to contribute to the project on the grounds that it would serve to "project" their regional cultures onto the Djakarta stage for the international tourist. But she also went on to say that: "If in the olden days, our ancestors worked cooperatively together (bergotong-rojong) to create the Borobudur, which now commands the attention of the whole world [it is not clear whether this reference was to the Borobudur's beauty or its current state of disrepair], today we too can work cooperatively to build the Beautiful Indonesia in Miniature Project."36 In response to what she felt was intemperate criticism, the President's wife told reporters on December 15 that "Whatever happens, I won't retreat an inch! This project must go through! Its implementation won't retreat a single step! For this project is not a prestige project--some of its purposes are to be of service to the People. The timing of its construction is also just right--so long as I'm alive. For someone's conception cannot possibly be carried out by someone else, only by the conceiver herself--unless I am summoned by God in the meantime!" 37 The opposition continued, however, and the head of state was finally forced to take matters in hand. In the wel1-known "Pertamina" speech of January 6, 1972 he said: "Quite frankly, I'11 deal with them! No matter who they are! Anyone who refuses to understand this warning, frankly I'11 deal with them! If they go on making trouble, it's no problem for me! I'll use Supersemar!" He went on to reveal that the project was intended to make Indonesia known to tourists and to raise national consciousness. As he put it, since there were so few remains of Madjapahit and Sriwidjaja, new things were needed to raise national consciousness and pride. 38

To get a fully sense of the meaning of Mini, it may be useful to look at some other New Order monuments, noting for the moment only the way the President and his wife linked it to the glories of the ancient Indonesian past. The traveler returning to East Java in recent years will have been struck by the extraordinary proliferation of public monuments in that region, which, not wholly coincidentally, contains the ruined monuments of Madjapahit. These constructions take a variety of shapes. One finds, for example, on the outskirts of Ponorogo, a large concrete replica of a major temple of the Panataran complex near

given in compensation was of much lower quality. (For details, see Tempo, May 20, 1971.) The student protests began on December 16, 1971 in Djakarta, spread to Bandung by December 23, and to Jogjakarta by December 28. (For details, see Sinar Harapan, December 16, 23 and 28, 1971.)

36. Sinar Harapan, December 1, 1971.

37. Harian Kami, December 16, 1971. Italics added. Here Mrs. Suharto used the Javanese term mumpung which subsequently has become something of a byword in Indonesian political parlance. Mumpung means, more or less, "so long as" or better "so long as I have the opportunity." For more on mumpung, see below at pp. 38-39.

38. Harian Kami, January 7,1972 . Supersemar is an acronym for Surat Perintah Sebelas Maret (Order of March 11), the document signed by Sukarno on March 11, 1966, transferring all executive authority to the then General Suharto. The acronym is also a wajang rebus: super = super, Semar is the all-powerful senior punakawan and elder brother of Batara Guru (Shiva). 

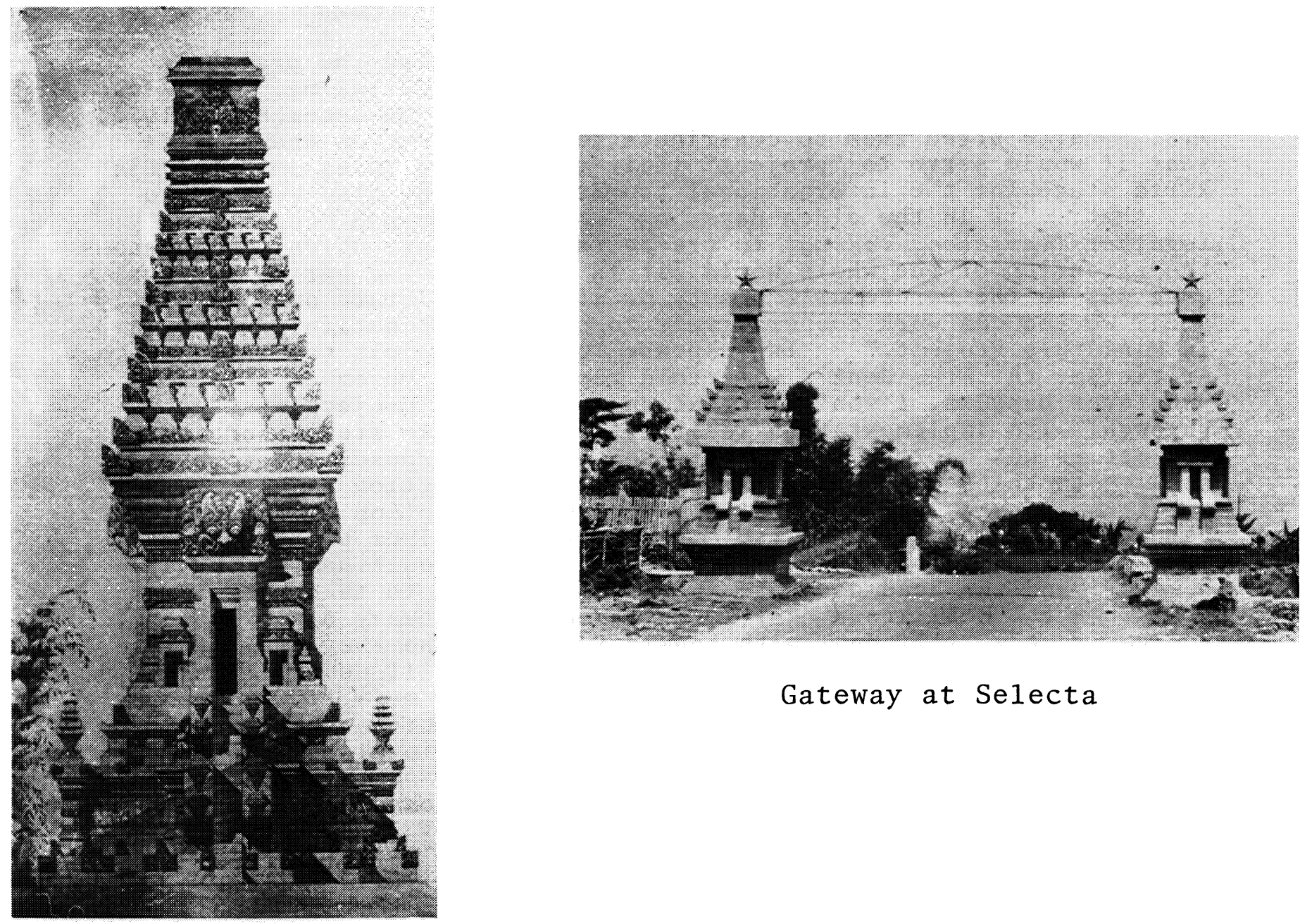

Gateway at Selecta

Sketch of Tjandi Sumberdjati, 14 th c. burial temple. Photo: Claire Holt.

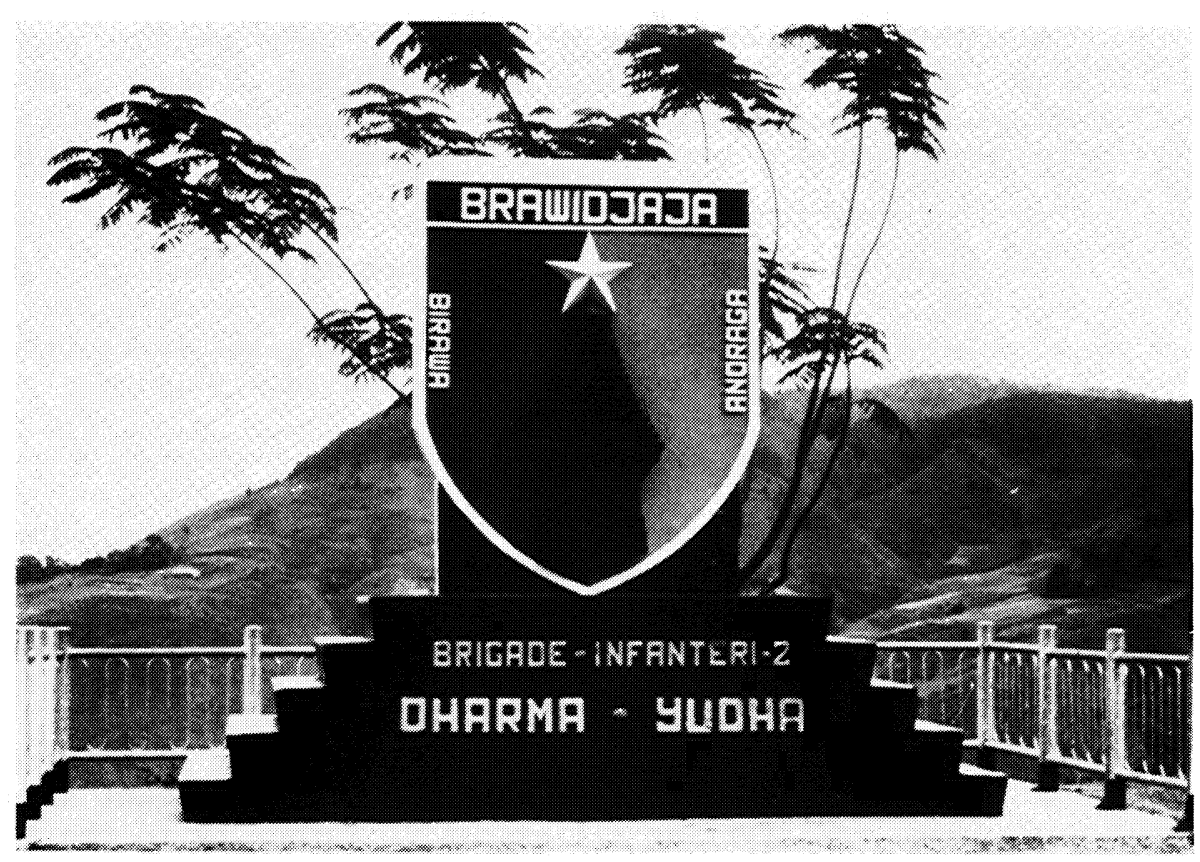

Brawidjaja Monument in West Sumatra. Photo: T. Kato. 
Blitar. 39 The main entranceways to the town of Tulung Agung are flanked by yellow-painted guardian raksasa, reduced versions of the great demonic statues that guard the gateway to $\mathrm{Tj}$ andi Singhasari, and similar to the little giant-demons found in front of the royal palaces of Central Java. 40 Across the main road leading into the mountain resort of Selecta a permanent archway has been constructed, consisting of two "East Java"-style meru linked over the motorists' heads by a cat's-cradle of horizontal metal trelliswork. 4 And in countless villages along the highways through the province the eye is caught by strange new portals at village entrances and before the doors of the more prosperous wayside houses: strange, because they consist of mansized concrete numbers painted red--1 and 9 to the 1 eft, 4 and 5 to the right (see frontispiece).

The cumulative effect of these innumerable objects is impressive: they represent a sustained program of monumental construction and distribution far surpassing the efforts of the Sukarno years, and possibly without precedent in Indonesian history since pre-colonial times. So one asks oneself why these forms? What is bejng said? One notes, first of all, that many of the monuments appear at first sight as replicas of ancient ruins. But closer inspection shows that the ruins are at once copied and not copied. What is typically replicated is the "general shape" of the ruin, so that, as it were, the passerby immediately understands the reference. " $O f$ course, the temple at Panataran!") At the same time, though funds were clearly not lacking for the program of construction, and East Java has no lack of talented artisans, little attempt has been made to reproduce the gracefully executed reliefs and ornamentation of the ancient model. The workmanship often seems clumsy and hurried. The replicas begin to look more like signposts than reproductions. ${ }^{4} 2$ And indeed, as we shall see, in a way they are.

39. For the original, see Kempers, Ancient Indonesian Art, P1ates 271 and 274; and Ho1t, Art in Indonesia, Plate $6 \overline{5}$.

40. Kempers, Ancient Indonesian Art, Plate 239.

41. See plate opposite of a Madjapahit-period meru portal from Trawulan. The insignia of the East Javanese Brawidjaja Division consists of this type of meru with a star on top. (Most of the East Java construction has been done under the Division's auspices. The same energy has been put into monument-building in areas like West Sumatra where the Division has been in occupation since the rebellions of 1958.)

42. In the mid-1950's a group of well-known Indonesian artists, including Zaini, Oesman Effendi and Trisno Sumardjo, were commissioned to do a series of plates for school use, showing important moments and aspects of Indonesian history. One of the strangest in this series is a picture called "Barabudur" by Oesman Effendi. Here the Borobudur appears "as it might once have looked," plastered gleaming white, undamaged, upright, symmetrical and magnificent. Closer inspection, however, shows that the immediate glory of the Borobudur, its incomparable reliefs, are not even blurredly represented; more importantly, there are no people at the shrine, though the painting is supposed to convey to children the living actuality of the legendary Shailendra age. What one sees, in effect, is a brilliant, deserted shape: not a recreation of the past, but a sign for it. That the singular character of this painting is no accident is shown by others in the series not painted by Desman Effendi. The greatness of the seventeenthcentury empire of Mataram, for example, is depicted in two works by Trisno 


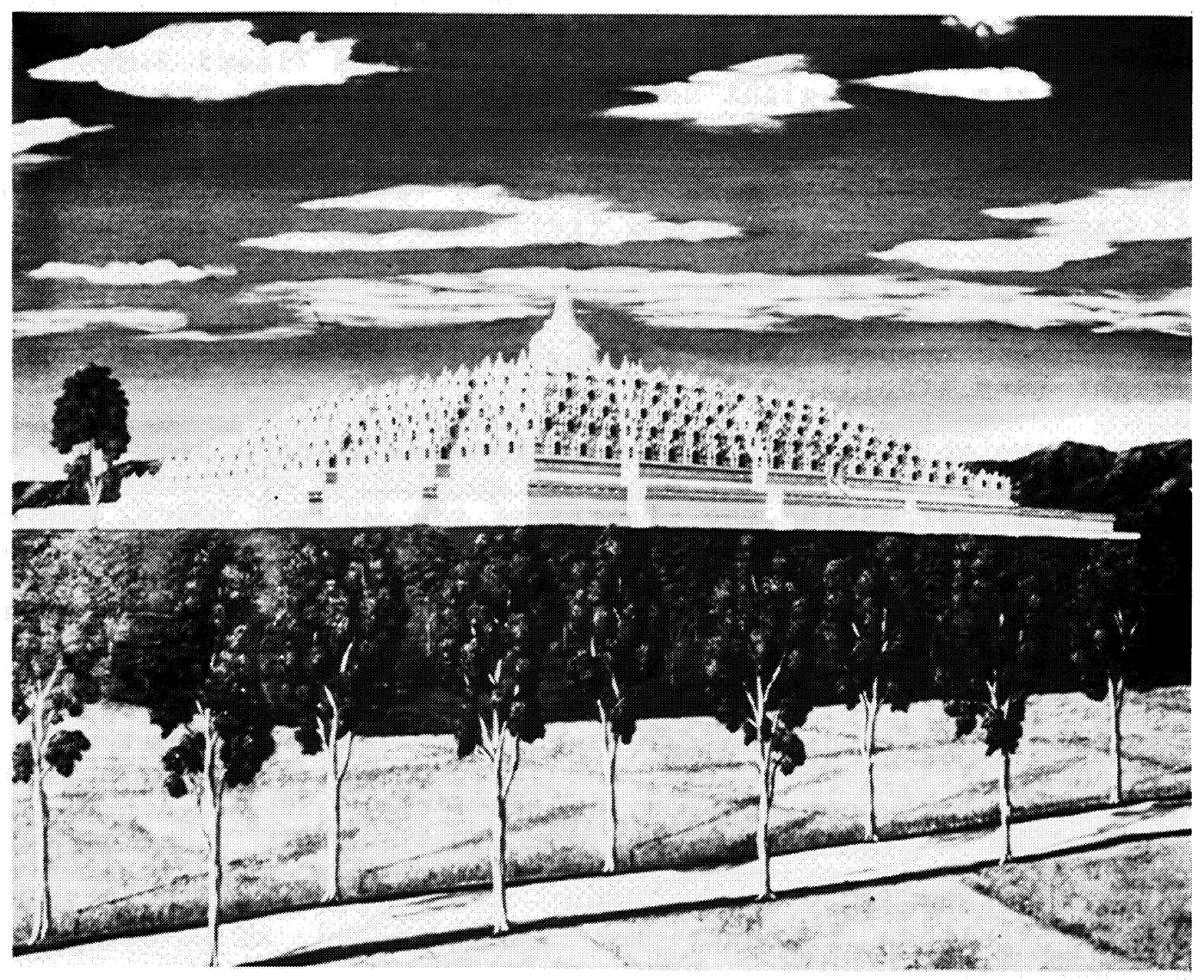

"Barabudur" by Oesman Effendi. Photo: Claire Holt.

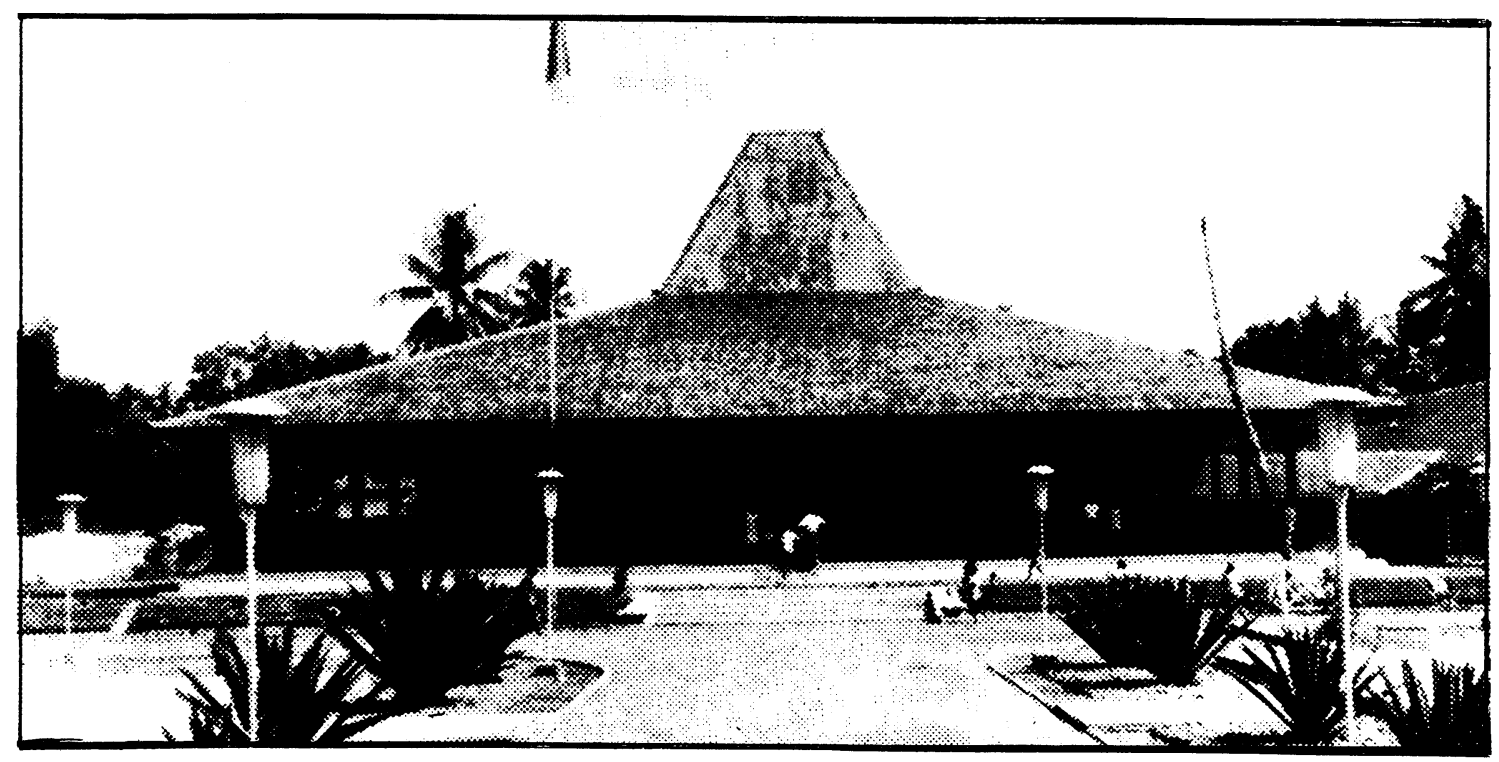

Tegalredjo complex. (Tempo, February 26, 1972) 
Another interesting monument, in the same vein, is the Tegalredjo complex under construction outside Jogjakarta. The site is believed to have been that of Pangeran Diponegoro's puri (palace/quarters) during the Java War, though all that survives seems to be a blasted mangosteen tree. Inaugurated by General Surono in August 1969 and financed by the Rumpun Diponegoro ("Family" of the Diponegoro Division of Central Java), the monument consists of a large 150 by 60 meters fenced-in compound containing a large pendapa (traditional Javanese audience-hall) decorated with reliefs of Diponegoro's exploits, two game Zan from the Jogjakarta Kraton and some antique Djepara chairs; a museum; a library; an administrative office; and a mosque. The shape of the structures is traditional--"to stir people's memories of ancient days." A special inscription (prasasti) has been put up which reads: "Al1 the members of the Diponegoro Division Family, Inheritors of the Heroic Fighting Spirit of Pangeran Diponegoro, have built this Diponegoro Monument on the site of the Pangeran's former puri in order to venerate and record the Fighting Spirit of the Hero Pangeran Diponegoro for eternity." 43

One is reminded of the somewhat bizarre episode in which Prince Norodom Sihanouk had a sizeable miniature replica of the Bayon constructed and put on display in the Phnom Penh national sports stadium as part of the celebrations commemorating the fifteenth anniversary of Cambodia's independence. The replica was used for that particular part of the celebrations in which the Royal Khmer Socialist Youth "paid tribute to Samdech 'Father of Independence.'"44 The Cambodian leader's construction is particularly apposite in this context, for the Bayon was constructed by Jayavarman VII to be the center of the city of Angkor, a city which was in its own way a "Mini" of the abode of the gods. 45 But Jayavarman, his sculptors and his architects, built their "Mini" from the mind's eye, creating a monument of unprecedented grandeur and beauty as it were "on the model" of an unseen heavenly city.

Sumardjo and Zaini: one shows the deserted tomb of Senopati in Kuta Gede, the other the no less deserted mausoleum of his grandson Sultan Agung at Imogiri. It is strange enough that glory should be expressed by tombs; but in addition, these tombs are not presented realistically as they appear to tourists and pilgrims today, nor are they depicted in any historically realistic sense. The simplicity, emptiness and sheen show that what one has here is again a sign. The connections between these signs from the 1950's and those of the 1970's are by no means clear, though it does not seem surprising that these three "mortuary" artists ended as adherents of the New Order.

43. Tempo, February 26, 1972. Italics added. For all the archaism of the above, the Rumpun Diponegoro is evidently aware of the needs of the times. A guesthouse is to be built behind the pendapa for tourists wishing to see performances or to meditate (njepi). Plans are afoot for the later construction of a modern tourist hotel and a shopping plaza. The authorities have indicated their strong desire to attract tourists, except for those in T-shirts and long hair.

44. See Kambuja, 45 (December 15, 1968). I am indebted to Mr. Dieter Bartels for this reference.

45. On the royal Southeast Asian city as a planned microcosm of the heavenly macrocosm, see R. Heine-Geldern, Conceptions of State and Kingship in Southeast Asia (Ithaca, N.Y.: Cornell University, Southeast Asia Program Data Paper No. 18, 1956), especially pp. 3-4. 
Sihanouk's portable Bayon, however, was not only a "Mini" of a "Mini," but meant something quite different from its model. It was a claim to the national past, not a creative elaboration of it. As in the case of the Indonesian monuments we have been looking at, Bayon II is a gloss, produced by a changed consciousness. Secondly, like the Indonesian monuments, it is, of course, an advertisement for the legitimacy of a ruler, a legitimacy, however, conceived less in terms of legalbiological than of cultural genealogy. 46

To return, then, to the Projek Mini, which we can now interpret as in many ways analogous to Bayon II, Tegalredjo and so forth. Traditional Javanese, Batak, Minangkabau or Toradja houses, 1ike Jayavarman's masterpiece, draw their beauty and power from their generation in contemporary and living cultures. All were or are, in a sense, built for the present and the future. Even when they are constructed today, in the landscapes which gave their forms birth, many continue to embody long-standing meanings. The general forms are firmly established, but in countless sma11, personal variations of ornament, texture and proportion, they are, for their inhabitants and their neighbors, unproblematic and full of presentness. In other cases, however, these houses are becoming "monuments" in the sense that they are no longer lived in, have become museums, or are painfully reconstructed to advertise the essence of tradition. In Djakarta, Surabaja, Medan and Makasar, new urban dwellings are being built which provide a clear stylistic link between the rumah adat and Mini's "rumah adat." One may find, for example, a successful Minangkabau businessman erecting for himself not a Minangkabau adat house, but rather a "Minangkabau-style" house, identified as such by an adventitious agglomeration of "Minangkabau" decoration or by an abstracted motif (the typical "winged roof," for example). These formal elements enable the owner to advertise to his neighbors and passers-by that here lives a successful Minangkabau: Minangkabau by the winged roof, successful by the Singapore-modern interior decoration and living space. ${ }^{47}$ Motif in such cases is totally separated from function and serves only to communicate a message of Minangkabauity. In the future Mini, all this will have gone one step further, since the houses will be "pure adat" and no one wizl live in them. Warehouses of regional artifacts, they will in effect be icons of ethnicity. Mini itself, as a whole, will be an icon of "Indonesianness" generated by the formal juxtaposition of these ethnicities. Its significance will be all the more salient to the extent that concrete and immediate life is drained from its architectural components. Nothing more poignant, in a way, than that this sign-for-Indonesia should be located in the living heart of the metropolis where Indonesia is so much in becoming; indeed that living Indonesians have to make way for Indonesian-ness.

46. On the Javanese way of using a special type of genealogy as a sign of power, see my "Idea of Power," pp. 25-28. In contrast to Western emphasis on genealogical descent as a legal concept, the Javanese stress is on cultural linkage. The contemporary variation on this tradition is that aside from claiming power on the basis of possession of, say, Sultan Agung's kris, one constructs a replica of the kris, as a "power-less" imaginary sign for power.

47. Compare the discussion of "Basque" architectural motifs in Parisian suburban housing in Roland Barthes' elegant Mythologies (New York: Hill and Wang, 1972), pp. 124-25. The difference between Paris and Djakarta, however, seems to be that whereas Parisians affect Basqueness without being in any way Basque, in Djakarta it is unlikely that any but Minangkabau would build "Minangkabau" houses or any but Batak "Batak." 


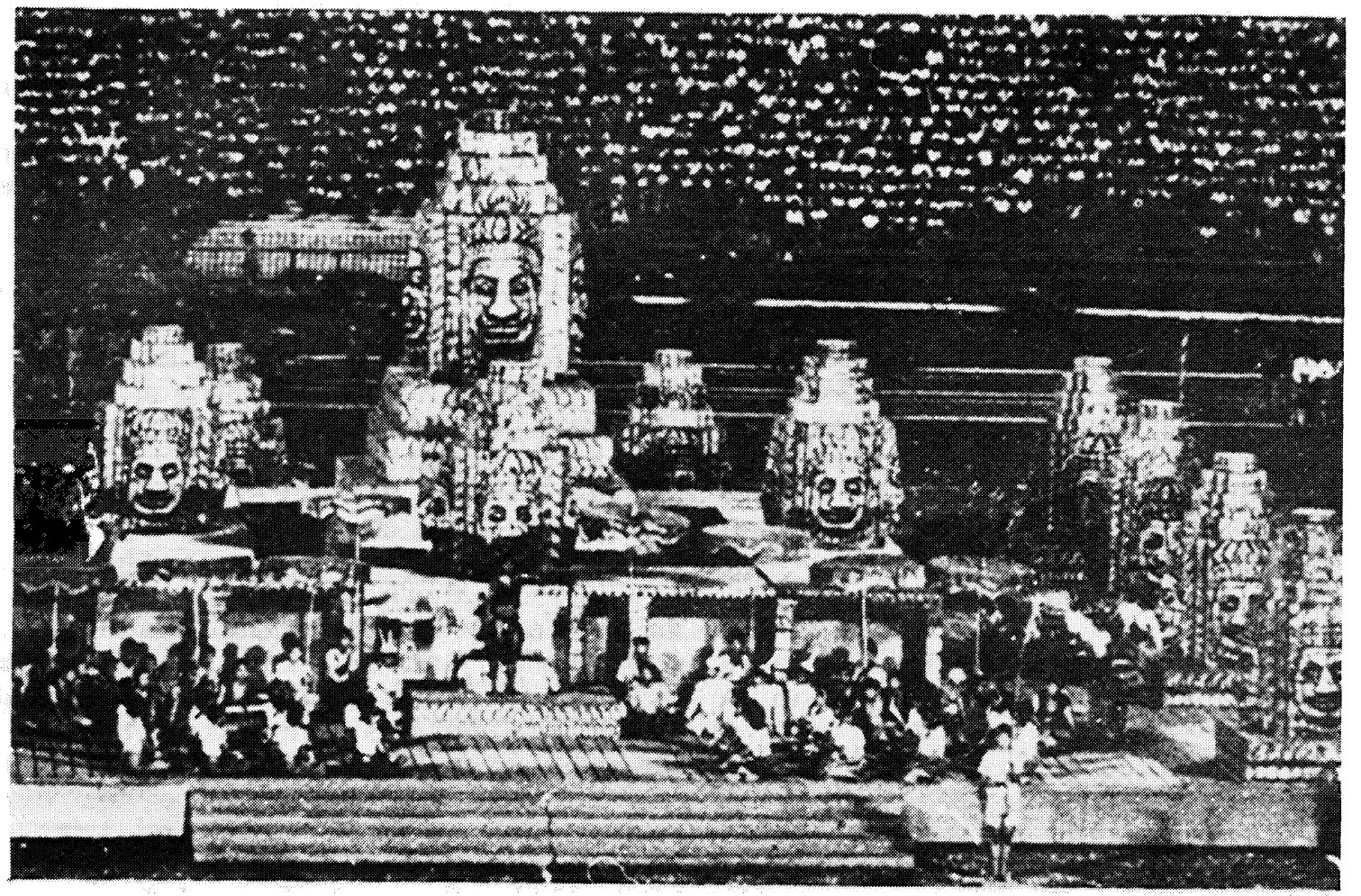

Bayon II (Kambuja, 45 [December 15, 1968])

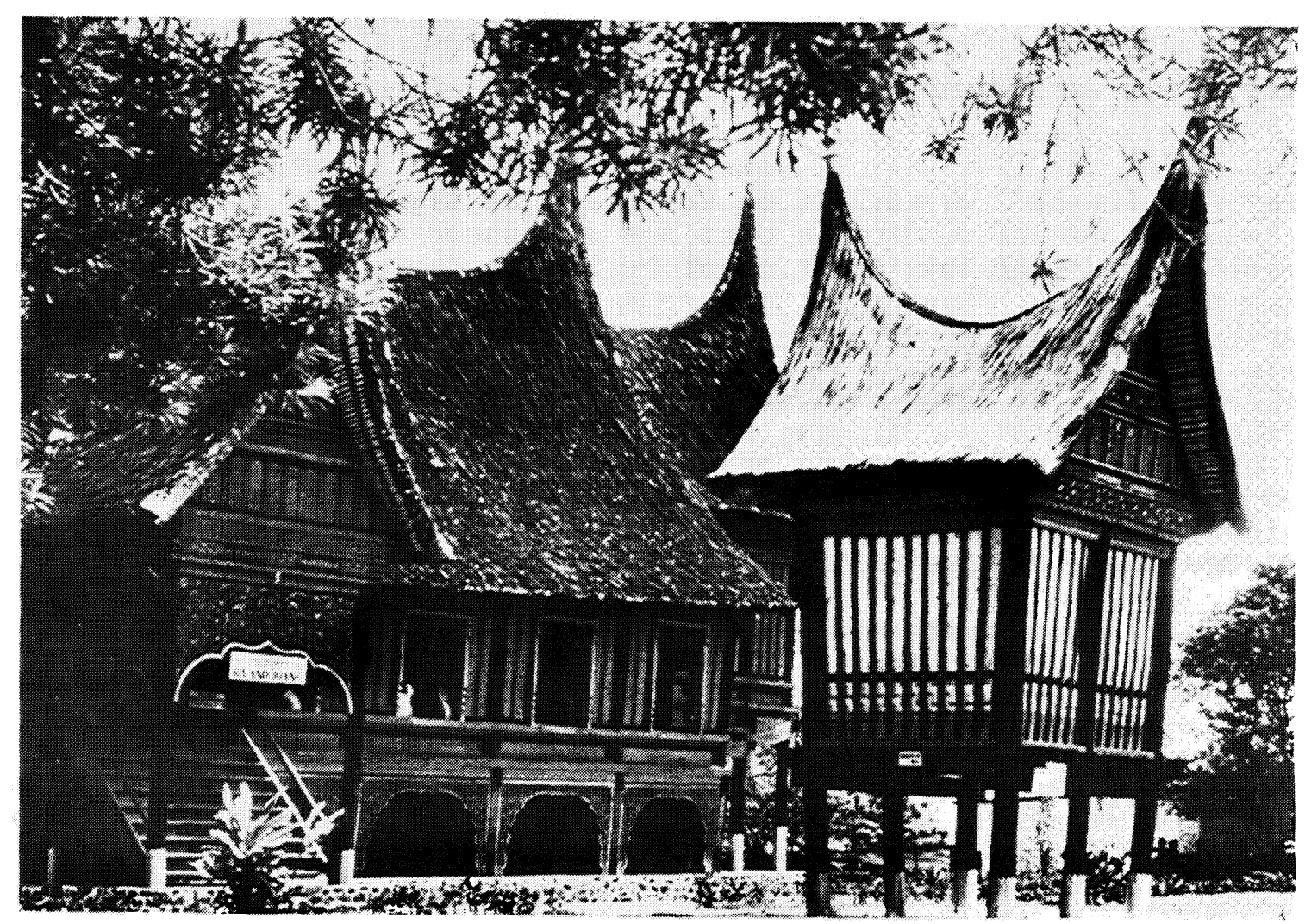

Bukittinggi Museum. Photo: Claire Holt. 
To sum up, then, it seems that a common element in many of the New Order's public monuments lies in an idea of "replication," designed to reveal essence and continuity rather than record existence and change. But to show that this idea need not express itself solely in archaism and replication, one very different monument may perhaps usefully be mentioned. This is the Yani Museum, which has been established in memory of the former commander of the Indonesian Army who was murdered during the October 1, 1965 Affair. It can hardly be said that the Museum is housed in General Yani's well-appointed home, for the Museum really is the home, which has been turned into a monument by two contrary types of alterations. First, a few specific mementoes of the Affair have been lodged in it: the gun with which the Communist leader, D. N. Aidit, was executed lies in a glass cabinet above Yani's bed; the spot where Yani fell has a large plaque embedded in the flooring; and so on. Second, almost anything that might have been peculiarly and personally Yani's has been removed. The walls of the house are lined with signed photographs of visiting dignitaries, gifts received on trips abroad, tokens and insignia of various Indonesian military units, army uniforms, a few conventional Indisch landscapes, some trophies, and so forth. The house is Yani's house, and yet it already has the feeling of a "rumah adat." Yani's life has been almost completely drained off. One would guess nothing of his reputed charm and intelligence, his meteoric career, his conspicuous life-style, or even of his habits and beliefs. Though the events commemorated are less than a decade old, and the monument is in every way "modern" and "untraditional" in form, one sees the link with the archaism of Tegalredjo: both are signs for "tradition." One could easily imagine the Museum being decorated with a prasasti of its own: "All the members of the Family of the Indonesian Army, Inheritors of the Heroic Fighting Spirit of Achmad Yani have built this Yani Museum on the site of Yani's former puri in order to venerate and record the Fighting spirit of the Hero General Yani for eternity."

Bequests and Inheritances

Finally, we turn to the immediate historical interpretation of the style of political communication we have been trying to identify. On March 2, 1972, General Djamin Gintings announced to the public, after conferring with the President, that he had received from Suharto some guidelines on how "the spirit and soul of ' 45 might be passed on to the younger generation."48 A week later, General Jasin, Deputy Army Chief of Staff, revealed that the forthcoming Army Seminar would discuss the integration of the Army Younger Generation and the Ordinary Younger Generation, to achieve harmony between them and to implant in both a love of country. Thereby the object of "drawing society closer to the Armed Forces" would be achieved.49 Opening the Seminar on March 13, President Suharto observed that while scientific and technological knowledge could be learned from abroad, "the source of leadership,

48. Harian Kami, March 3, 1972. Gintings was a prominent leader of the so-called Musjawarah Angkatan ' 45 (Consultative Council of the 1945 Generation), formed in the Guided Democracy period to bring together veterans of the Revolution.

49. Harian Kami, March 10, 1972. It was specified that the Seminar would be attended by about 500 people, including Army chiefs, alumni of the Army Staff and Command College (Seskoad), some civilian intellectuals, but no "pedjuang diluar ABRI

(freedom-fighters outside the Indonesian Armed Forces)." 
character and determination as a people building its future must continue to be drawn from the history of our own struggle and our own identity." The present grave danger was "indications of an estrangement of the younger generation precisely from the history of the national struggle and the national identity. . . The consequence is that they tend to orient themselves towards an alien culture not their own." If this process were not halted, in one generation their own culture and identity would be irretrievably lost. He urged the members of the 1945 Generation to take cognizance of their own actions and style of 1 ife, and see how far they themselves lived up to their own values. Otherwise, their example would only alienate the young still further. "We need to arm ourselves with the philosophy of devoted service to state and nation taught by Mangkunegoro I in his Tri Darma. The first Darma is rumongso handuweni--to feel that one has a share of something which is the property or interest, the property or interest of the state and nation. From this feeling there arises the second Darma--wadjib mè $z_{u}$ hangrukebi--meaning to share responsibility for defending and sustaining this common property or interest. To carry out this first and second Darma, a thirl is needed, in other words, mulat sariro hangrosowani, meaning to have the courage constantly to examine ourselves to see how far we have really acted to defend the common property or interest." 50

Other officers expressed themselves in less philosophical terms. Thus Army intellectual General Sajidiman remarked: "The problem is how to convince the younger generation of the truth of the values of ' 45 as the Generation of ' 45 is itself convinced." Only during the Revolution, fighting and suffering with the People, realizing that if one deviated from the Pantja Sila one was destroyed, did his generation truly understand the truth of these values. General Darjatmo observed that the values of ' 45 were "steadfastness of heart to struggle for the interests of the people, an unconquerable spirit, the basic principles contained in the Prologue to the 1945 Constitution and the Pantja Sila.. all of these values infuse the New Order at the present time." Finally, General Sumitro spoke directly to the younger generation in the following terms: "There is no good reason why the younger generation should not have full confidence in the older generation, for the older generation has bequeathed to them its doctrines, which are the products of its experience, although the younger generation will always have the right to test the truth of these doctrines in institutions of education." 51

old themes undoubtedly, at least at first sight. Suharto is not the first leader to quote Javanese adages, or Sumitro a pioneer in transforming values into doktrin. One recalls Sukarno appealing to Indonesians to "return to our Revolution," to go back to the "track of our Revolution," and "never abandon history." But there is also an obvious difference. Sukarno made his appeals to people who had once

50. Harian Kami, March 14, 1972.

51. Harian Kami, March 16, 1972. Italics added. Not all of the Seminar participants seem to have shared Sumitro's assessment. Shortly afterwards, General A. H. Nasution was quoted as saying that at the Bandung Commanders' Call (meeting of territorial commanders which immediately preceded the Seminar) he had observed many generals whose bellies protruded above the tables at which they were sitting. "When I was Army Chief of Staff, this sort of thing never occurred." Indonesia Raya, March 28, 1972. Nasution was Chief of Staff from 1950-52 and 1955-62. 
been "in the Revolution," had once been on its "track" and had once "made history." He spoke to the memories and conscience of a community which had shared a climactic historical experience, but which, as he saw it, had allowed itself then to become divided, corrupted and demoralized. Suharto and his generals, however, are more and more speaking to groups who do not share that experience, except in the most tangential way. The links are now less those of a shared political enterprise than those of kinship, in all its ambiguity. Hence a new language of "inheritance" and "bequest."

Kinship, however, is thought of and used in two parallel but different ways. At one level, it is a metaphor for the overall relationship between generations in Indonesian history, and for what links the present to the Revolution. 52 Whatever conflicts may exist between old and young in Indonesia, all the same they are conflicts "within the family" as the concept of generation in itself implies. Young and old, rulers and opposition are "masih famili," as Djon Domino would put it. At a second level, kinship has more direct sociological significance. Only a very small, urban and privileged minority of Indonesian youth can reasonably be regarded as so oriented to foreign culture as to be in danger of losing "its culture and identity." And this minority is naturally largely composed of the extended families of Indonesia's contemporary ruling class. In many ways, then, the generals are speaking to their own children within an all-Indonesian symbolology.

For there is a real and painful paradox in the position of Indonesia's rulers. They wield vast power over the political life of the nation, but find the culture, morals and values of their younger kinfolk increasingly out of their control.53 There is a prevailing feeling that established values are rapidly disappearing in certain youth circles. This is less a matter of such causes célébres as the sum Kuning gang-rape case (which involved children of the Jogjakarta elite and was therefore never properly cleared up), than of general style.

52. It has long been a tradition to periodize Indonesian political and cultural history by generation. There is a rough correspondence between the political sequence: Angkatan '28 (the year of the celebrated Oath of Youth)--Angkatan '45 (the year of the Proclamation of Independence)--Angkatan 166 (the year of Sukarno's overthrow) and Pudjangga Baru (writers of the 1930's)--Angkatan ' 45 (writers of the Japanese Occupation and the revolutionary years)--Angkatan ' 66 (writers of the postrevolutionary years). There are a number of interesting polemical works on this theme, particularly in the literary field (where divisions by generation are especially problematic). For some pieces on the controversy surrounding the concept of the Generation of 166, for example, see: H. B. Jassin, "Angkatan 66, Bangkitnja satu generasi," Horison, I, 2 (August 1966), pp. 36-41; Satyagraha Hoerip, "Angkatan 66 dalam kesusasteraan kita," Horison, I, 6 (December 1966), pp. 188-89; Aoh K. Hamidjaja, "Daerah dan Angkatan 66," Horison, II, 2 (February 1967), pp. 58-60; and Rachmat Djoko Pradopo, "Penggolongan angkatan dan Angkatan 66 dalam sastra," Horison, II, 6 (June 1967), pp. 165-68.

53. People in Djakarta frequently comment on how few children of well-known pedjuang have "djadi orang (made respectable careers for themselves)." They shake their heads at the numbers who have become band-leaders, fashion mode1s, criminals, tourist agents, PR-men, call-girls, and what not. The facts are usually attributed to parental spoiling or to the great opportunities for social mobility which independence has offered, such that "outsiders" have been able to reach the positions that these children would have inherited in an earlier age. There is probably an element of truth in both suggestions. 


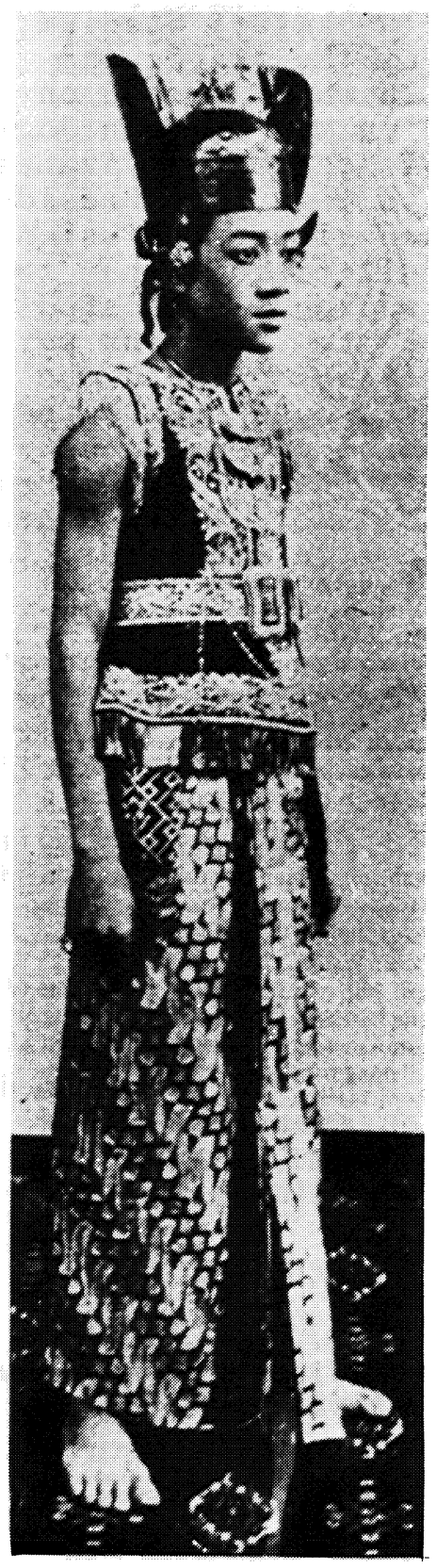

The youthful sultan

Hamengkubuwono IX

(Tempo, December 11, 1971)

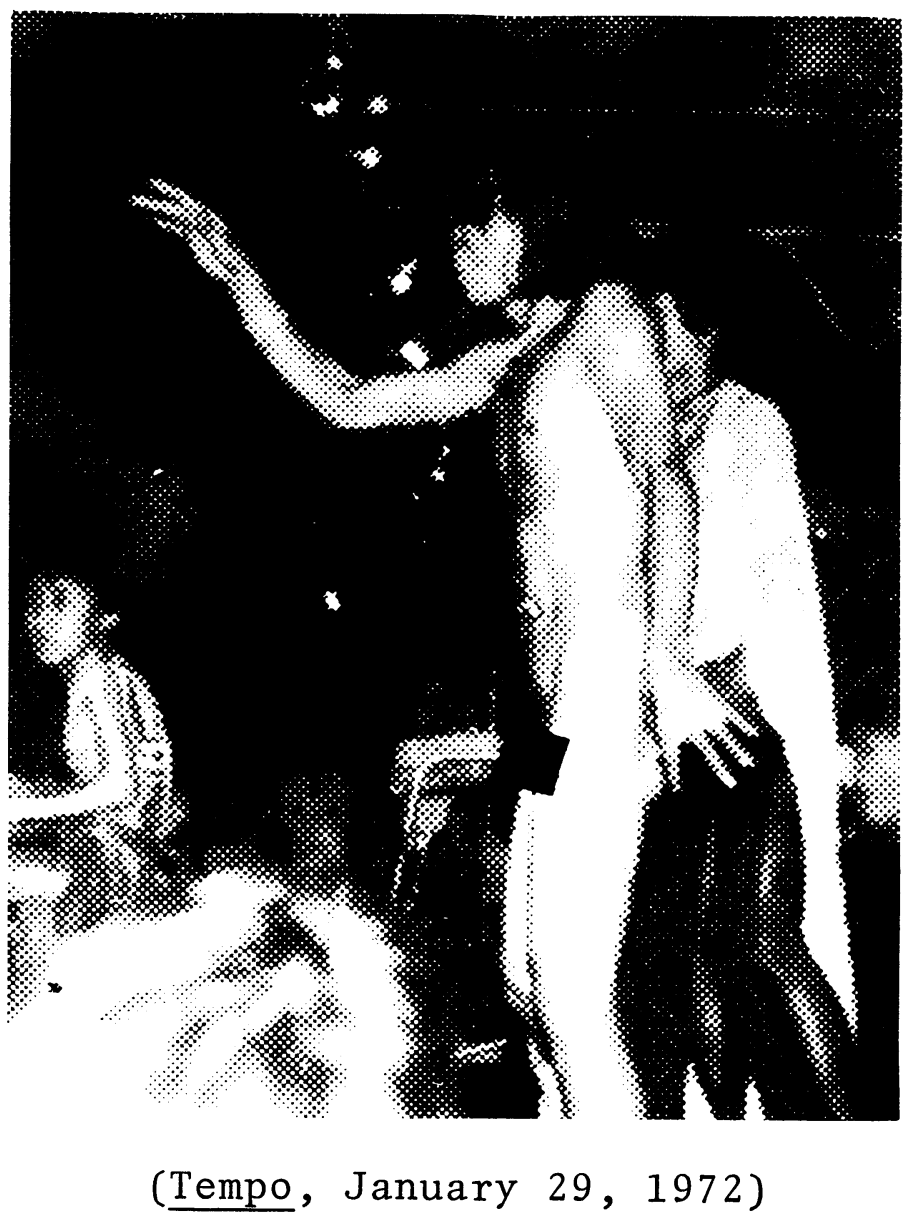


Two recent ironic episodes illustrate what this concern is about. In Surabaja the 1972 New Year celebrations were the occasion for holding a contest to select a "King" and a "Queen" of Freaks (orang eksentrik). The competition seems to have been fierce: all kinds of outré clothes were displayed; some youths simulated sexual intercourse with a group of young transvestites; and a certain Udjang went so far as to strip nude and exhibit himself before the crowd. The irony of the episode lay in the choice of the arena for the contest: Tambaksari stadium, entitled Flaming Spirit of November 10 in memory of the tragic and heroic battle of the Surabayans against the British which opened on November 10, 1945.54 The second scandal occurred in May 1972 in Jogjakarta, traditionally a conservative and respectable center of Javanese culture, the Revolutionary capital between 1946 and 1949, and President Suharto's place of provenance. The authorities had given permission for eight local bands to perform on a local football field. When these bands finally wished to pack up and go home, the audience protested violent1y. As the national weekly Tempo described it: "Buttons were torn open. People pushed forward to the dais. One boy climbed the collapsible ladder by the stage, exposed his genitals and rubbed them against the metal. Another opened his underpants and caressed 'himself' openly before the public. Another leapt onto the dais and began kissing the drummer who was wearing half-female costume. It was then that the police made their appearance on the stage. On the orders [of the police commander], the performance was then closed."55

Such events suggest to Indonesia's rulers that the future threat ens to elude them and so the past is summoned to their aid. Most of them are deeply aware of the drastic journey they have made in their lives from the rural townships of late colonial Java to the metropolitan pomp of the "cosmopolitan" Djakarta they now enjoy. Given this abrupt, almost fortuitous transition, it is not surprising that their present power at times feels adventitious. In part, this is the basis for that mumpung psychology, to which I have previously referred. 56 (Another part, as can be seen from Mrs. Suharto's remarks, is middleaged intimations of mortality.) But there is more involved than adventitiousness of power. Their past has also not prepared them morally for the lives that they now lead. Most of them grew up in the sphere of provincial Javanese society, and the norms and ethics of that society form powerful residues at the core of their consciousness. For such provincials, tags drawn from the Tri Darma or from Mangkunegoro IV's Tripama do represent the real and solid basis of Javanese tradi-

54. For details, see Tempo, January 29, 1972.

55. Tempo, May 20, 1972. What was scandalous here was the public display of sexuality by "upper class" people, not their private sexual behavior (about which traditional Java has generally been tolerant).

56. See above, p. 27. It is instructive to compare this with a section of the defense speech of the senior PKI leader Sudisman before the Extraordinary Military Tribunal on July 21, 1967. "To remind us of our limitations and to keep our feet on the ground, we Javanese often use the phrase adja dumeh--a phrase I find very hard to translate exactly into Indonesian. If one analyzes why this should be so, it is because people who dumeh kuasa and act arbitrarily are usually politely warned with the words adja dumèh." Dumèh is very close to mumpung: thus dumèh kuasa means "just because (I) happen to have the power"; and adja dumèh "don't, just because you happen to (have the power). . . ." (The quotation is from an unpublished translation of a typescript of the trial proceedings in my possession.) 
tion. When Suharto quotes Mangkunegoro I, his words are not a gloss on tradition, like Mini, but a real expression of it. Furthermore, for most of the men and women of Suharto's political generation, the Revolution of 1945 was a profound moral experience and a creative act of fundamental value. The egalitarian solidarity to which General Sajidiman referred at the Army Seminar was not a rhetorical fiction, but was a basic element of the revolutionary ethos.57 Yet that experience is a quarter of a century in the past; General Sajidiman and his colleagues now live in opulence far away from the people. At the same time, little in the postrevolutionary experience has allowed for the creation of a new moral stance which would permit them to deal with their present circumstances with real inner tranquilitit. Pembangunan (Development) has no more than instrumental implications, and derives whatever moral thrust it has from the revolutionary ethos of the past. The contrast between circumstance and ethos has led, accordingly, to the congealing of values into doktrin. The values of 1945 are turned into the doktrin of the Values of 1945. Pantja Sila Democracy and Pantja Sila Economy, phrases which evoke the memory of Sukarno's great speech of 1945 proclaiming the moral basis of the independent Indonesian state, are doktrin too, icons claiming a coherence of present and past, or the life of the past in the present, though they are experienced by many as their fundamental negation--military authoritarianism and an economy subjected to foreign capital.

The children, however, have grown up in the sphere where their fathers' journeys ended. They are not provincials come to the metropolis, but natural denizens of the new urban centers. The lives they observe and lead themselves are not clearly linked to the ethos either of the Revolution or of Tri Darma. For them the moral tensions which under1ie their parents' 1ives--Pantja Sila live vs. Pantja Sila doktrin, wadjib mèlu hangrukebi vs. mumpung--have little meaning. Their link to their parents' generation is less a moral or political link (they have their own city-bred ethos of competition, individualism, selfexpression, and so forth), than one of kinship. They are, after al1, "masih famili." One begins to see part of the meaning of that multitude of scarlet numbers scattered across the East Java countryside. The numbers, in their own way, are like Tegalredjo, the Monumen Nasional, and even Mini--attentuated glosses on historical experience. By a flattening of time, it is almost as if 1945 were as remote as 1830 . As the Diponegoro Family is "heir" to Diponegoro, so the younger generation family is to be "heir" to the Revolution. The numbers are signs for continuity with tradition.

The motifs outlined here are well delineated in a curious film which had its Djakarta premiere a few weeks after the 1972 Army Seminar closed. Lewat Tengah Malam (Past Midnight) is the story of a former pedjuang who, disgusted with the corruption and opportunism he sees around him in contemporary Djakarta, becomes a skilled professional burglar. Exploiting the entree which his revolutionary experience gives him into the fashionable homes of the capital's new rich--he is, as Djakartans say, binnen ("in")--he robs their safes and jewelry chests. Together with faithful comrades from the old days, he uses the loot to establish a productive factory in a poverty-stricken area of rural Java, treating the workers with paternal solicitude and care. Under his managerial alias he wins the loyalty and admiration of the

57. See my Java in a Time of Revolution (Ithaca, N.Y.: Corne11 University Press, 1972), especia11y chapters $2,3,7,8$ and 15. 
local population by his unselfish efforts to involve them in genuine pembangunan. But his downfall finally comes when he falls in love with a beautiful police-agent employed by his elder brother, an uncorrupted commissioner of the metropolitan police. The brothers finally confront one another. Each recognizes the sincerity of the other's motives. The hero agrees to surrender and serve his legally ordained prison term, while the police-agent promises to wait for him in patience.

What is most striking about the film is the counterpoint between its ethos and the movement of the plot. The moral leitmotiv is commitment to pedjuang ideals, the ideals of 1945; but the plot requires the hero--who is frequently referred to early in the film as a mysterious bandit intelèk (educated bandit)--to pretend to be a member of the corrupt and wealthy ruling class by dressing, drinking, driving and holidaying in a suitably ostentatious manner. (While the hero pretends to be decadently profligate in order to fool his victims, the policewoman pretends to be a "fast" woman of high fashion in order to fool the hero!) The hero's basic concern for the welfare of the people is thus consistent1y juxtaposed to his mod clothes and dashing sportscars. Only his melancholy expression signifies his real values, and is thereby a genuine mask of the traditional sort. On the other hand, if the contemporary situation makes the product of the bandit's robberies a "development" project, the moral impulse is not so much a drive to achieve "accelerated modernization," but rather the continuation of the spirit of '45. The characters in the bandit's group even ruminate on the Sajidiman theme of the pedjuang's dependence on the People in the Revolution and the need to repay the moral debt thereby incurred. Beyond that, another typical "traditional" theme is sounded in a romantic flashback in which the hero recalls his village boyhood, splashing carefreely in the ponds and running through the shimmering ricefields. It is no coincidence that this flashback occurs to the hero while he is on holiday in Bali (!), staying at a luxurious beach hotel with the disguised police-agent.

Finally, one notes the recurrence of the kinship motif. Burglar and police commissioner are, after all, real brothers. The tie that links them is that of family. But in addition, the hero's success in his criminal profession depends on his close social ties with Djakarta's nouveaux riches. He can steal from them with impunity because he is invited to their parties. Fortunately, he is, so to speak, "masih famili."58 Paradoxically, the link between kinship and 1945 is crimecum-pembangunan. It is as if the film were saying: "Yes, indeed, there are many rich and decadent ex-pedjuang in Djakarta, and yes, there is a lot of crime in high places, but don't be misled! The old revolutionary and traditional values are still there. Just look at the mask! Watch the pembangunan! In any case, be patient, wait and see how it all turns out!"

\section{Conclusion}

In a way, all the visual political communication that we have been discussing is at bottom related to the career, history and conscious-

58. Yet at the same time the hero has no children (though he must be close to middle age) and has little immediate prospect of having them. The issue of legacies therefore does not arise, perhaps not accidentally. 
ness of what, broadly termed, can be called the "revolutionary generation." In Indonesia today, we are watching a major social and cultural turning-point: the gradual passing of this generation. Scarcely a month goes by without the newspapers recording the death of yet another pedjuang. The proximate eclipse of this generation, in conjunction with the absence of dramatic political conflict in Indonesia for the present, allows us to reflect on the vast changes that have taken place in the twenty-five years that this generation has dominated the scene. On the social leve1, we observe the articulation of a fully Indonesian class structure both in the countryside (with the abandonment of 1 and reform and agrarian redistribution since 1965, landlordism and debt bondage have notably accelerated) and in the larger cities (where a weak, parasitic, but visibly prosperous indigenous middle class has emerged). 59 On the political level, power has been concentrated and stabilized in the hands of a reasonably unified military elite. 60 on the cultural level, a metropolitan mestizo culture has developed and spread, which is no longer adopted but grown up in. This is the reality of what the successors of the "revolutionary generation" will inherit. At the same time, as the Army Seminar shows, this is far from what the "revolutionary generation" sees (publicly, at any rate) as its bequests. The evident discrepancy between such bequests and such inheritances, between history as conceived by legators and history experienced by legatees, brings us back to the cartoonists with whom we started. Sibarani belonged (perhaps still belongs) to the "revolutionary generation." Partly because of his left-wing sympathies, partly because of the time when he did his best-known work, there is no question in his cartoons of legacies and bequests. Though the drawings are often full of darkness and horror, paradoxically they have an optimistic base. Real conflict was taking place in Indonesian society, and the future was not foreclosed. The promise of 1945 , in other words its continuity, was real and remained only to be fulfilled. The Revolution was by no means "selesai (completed)." His cartoons were directly political and indeed educational precisely for this reason. They showed intellectuals who were "really" bandits, not bandits who were "really" intellectuals. The spirit and values of ' 45 were things to be acted on, not encoded and bequeathed. If his cartoons' impulses came from the past, they pointed directly into the future. They were, to put it another way, completely traditional, in that they were submerged in history rather than commentaries on it.

59. Classes in part are defined over time by marriages. The consolidation of a ruling class is typically marked by endogamy. The society pages of the Indonesian press make interesting reading in this regard. "Family" power seems to function socially as financial and bureaucratic power do in the economic and political realms. For indications of increasing class differentiation and oppression in rural areas, especially since 1965, see, e.g., Mubyarto, "The Sugar Industry," Bulletin of Indonesian Economic Studies, V, 2 (July 1969), pp. 37-59; P. R. Duester, "Rural Consequences of Indonesian Inflation: a case study of the Jogjakarta Region" (Ph.D. thesis, University of Wisconsin, 1971); R. Franke, "The Javanese kangen family" (draft paper, 1971); D. H. Penny and Masri Singarimbun, "A Case Study of Rural Poverty," Bulletin of Indonesian Economic Studies, VIII, 1 (March 1972), pp. 79-98; Roger Montgomery, "Employment and Unemployment in Jogjakarta" (Ph.D. thesis in preparation, Cornell University, $1973)$.

60. On this topic, see Ruth T. McVey, "The Post-Revolutionary Transformation of the Indonesian Army," Pt. I, Indonesia, 11 (Apri1 1971), pp. 130-76; Pt. II, Indonesia, 13 (April 1972), pp. 147-81. 
By the middle years of Guided Democracy things had begun to change, and after 1965 the direction of that change was finally determined for the "revolutionary generation." With Sukarno it was still a question of "returning to" the Revolution as a real political possibility. Under the New Order, there is nothing to return to, and the spirit of 1945 is less to be acted on than to be bequeathed. Monuments, films and doktrin a11 attest to this changing consciousness. Lewat Tengah Malam is a form for showing that whatever the present is, it is really the past. The archaism of Mini, Tegalredjo and the East Java monuments communicate the same message in their different ways: essentially nothing has changed. Diponegoro's spirit, the 1945 spirit, Madjapahit's spirit are always with us. There is no need to return to them, because they are, by definition, here.

In Hidajat, we see the lineaments of the "revolutionary generation's" legatees. The white light of his cartoons reveals a fundamental pessimism under the comedy and farce. Nothing in his drawings suggests the possibility of change. The world they enclose is without real conflict, and thus, without a force within it which could alter it at all. If older characters appear, one would not guess that they are pedjuang or even ex-pedjuang. The generations are linked together in a homogeneous moral bond. If there is no explicit conflict or argument between generations in his strips, this should not conceal the fact that "no argument" itself distills a fundamental argument. The Revolution, the National Struggle, the Spirit of ' 45 are not part of real experience or lived tradition, and so may now appear as gleaming, depopulated Borobudur at best, or riddling doktrin at worst.

This brings us finally to a question raised early on: how are we to explain the absence of foreigners in Hidajat's cartoons, when Hidajat's Djakarta is so conspicuously filled with their dominating presence? The answer, I think, is that at bottom, the foreigners make no difference. Including them in the world of the cartoons would not change its character, but merely extend it further into space. Sibarani drew his Americans because their presence and actions were major contributing elements to the conflict he saw working itself out in his generation in his society. Dulles and Pope were counterposed to the Rakjat; together they represented two fundamentally opposed political forces and moral universes. In Hidajat's work, Nixon and Tanaka, or better, in keeping with his Djakarta style, local American and Japanese diplomats and businessmen, would be counterposed to nothing: they would merely be a further ramification of an indefinitely extended famili.61 For there are no more ratu, only a world of Petruk. What Djakarta is like today is in reality what the world is like: the city is in its own way an authentic "Mini." One discerns here a new perspective--pragmatism it has often been called, though it seems, in Hidajat's work, to be a more complex blend of irony and resignation. What one observes, however, is that with Hidajat, we are back in the flow of history. His work, in its own way, shares Sibarani's immediacy, and, in style and content, is no less authentically traditional.

61. Lest it be thought that this absence is simply a matter of discretion, given the present intimate relationship between the rulers of Indonesia, the United States and Japan, it should be pointed out that even the enemies of the state--the Communists (domestic, Russian, Chinese)--never appear in the strips. If the inhabitants of Hidajat's cartoons are aware of the Indonesian government's constant warnings of subversive threats to the world they inhabit, they give no sign of it whatever. 